Irena Kraševac

Institut za povijest umjetnosti, Zagreb

Ariana Novina

Akademija likovnih umjetnosti, Zagreb

\title{
Planovi i faze gradnje Akademije likovnih umjetnosti u Zagrebu od 1895. do 1957. godine
}

\author{
Izvorni znanstveni rad - Original scientific paper \\ Primljen - Received 27. 11. 2020. \\ UDK 727:378 (497.5Zagreb)“1895/1957“ \\ DOI doi.org/10.31664/ripu.2020.44/2.08
}

\begin{abstract}
Sažetak
Glavna zgrada Akademije likovnih umjetnosti u Zagrebu građena je $u$ različitim etapama od 1895. do 1957. godine. U članku se prvi put detaljno analiziraju sve faze gradnje, počevši od Umjetničkih atelijera koje je 1895. projektirao Herman Bollé, dograđenih za potrebe Više škole za umjetnost $i$ umjetni obrt po nacrtima Victora Grossa 1907. godine. Prema projektu Cirila Metoda Ivekovića sklopu je 1921. prigradena dvokatnica s visokom mansardom, a kao posljednja velika intervencija uslijedila je trokatna dogradnja 1957. godine prema projektu Ive Geršića. Sveukupno pet objekata različitih autora i razdoblja gradnje čini
\end{abstract}

današnji jedinstveni arhitektonski sklop. Osim arhitekata projektanata, u članku se spominju i graditelji izvođači, Kuno Waidmann, Pilar, Mally \& Bauda, Josip Dubsky, Wutte i Mihok. Navode se i interpretiraju $i$ nerealizirani planovi i nacrti koje su izradili arhitekti Viktor Kovačić i Hugo Ehrlich (1908., atribucija), Rudolf Lubynski (1912.) te Srećko Florschütz (1914.). Tijekom prvih šezdesetak godina, od kraja 19. do sredine 20. stoljeća planirana je i izgrađena središnja zgrada u dvorištu Ilice 85, a u njezinoj su arhitektonskoj koncepciji i realizaciji sudjelovali tada najpriznatiji hrvatski arhitekti i graditelji.

Ključne riječi: Umjetnički atelijeri, Akademija likovnih umjetnosti, Zagreb, arhitektura, Herman Bollé, Victor Gross, Viktor Kovačić, Hugo Ehrlich, Rudolf Lubynski, Srećko Florschütz, Ćiril Metod Iveković, Jaroslav Albert, Ivo Geršić, Fanika Bihler

Likovne akademije specifičnim metodama kreiraju teorijsko i praktično znanje na polju vizualnih umjetnosti, koje prerasta u estetske kanone pojedinih epoha. Idealističko-filozofski razlozi utemeljenja likovnih akademija kao mjesta njegovanja lijepog i uzvišenog, te pokušaj etabliranja jedne humanističke profesije sežu u razdoblje renesanse. ${ }^{1}$ Do konca 19. stoljeća diljem Europe niču brojne umjetničke škole, pa svaka kulturna sredina dobiva mogućnost srednjega, odnosno višega akademskog obrazovanja u području likovnih umjetnosti, nerijetko formirajući vlastite specifičnosti kroz »klase« i »škole«. Važnost koju je društvo pridavalo umjetničkom školovanju naročito je potencirana gradnjom reprezentativnih zgrada za potrebe umjetničkih škola i likovnih akademija, koje su pozicionirane na atraktivnim gradskim lokacijama i djela su znamenitih arhitekata. ${ }^{2}$

Uvažavanje dugogodišnje tradicije kontinuiranog djelovanja zagrebačke Akademije likovnih umjetnosti u prostoru dvorišne zgrade u Ilici 85 , kao i činjenica da je upisana u Registar nepokretnih kulturnih dobara grada Zagreba, ${ }^{3}$ nameće potrebu boljeg poznavanja povijesnih okolnosti njezine izgradnje i procesa podučavanja umjetničkog rada koji se ovdje odvijao. Sagrađena za potrebe atelijera umjetnikā 1895./1896. godine, zgrada je ponajprije zahvaljujući viziji i upornosti onih koji su tu djelovali ujedno postala i sjedištem akademije, te akademija sama.

O društveno-povijesnim okolnostima Nagodbenog doba, ulozi i značenju Ise Kršnjavija za gradnju Umjetničkih atelijera te potom osnivanja Više škole za umjetnost i umjetni obrt, pisala je Olga Maruševski. ${ }^{4}$ Ovaj rad proširuje njezina istraživanja povijesti gradnje Akademije likovnih umjetnosti i proteže ih na razdoblje nakon 1918. godine, te sagledava cjelinu arhitektonskog kompleksa koji čini pet povezanih zgrada, koje su projektirali Herman Bollé, Victor Gross, Oton Iveković i Ivo Geršić. 


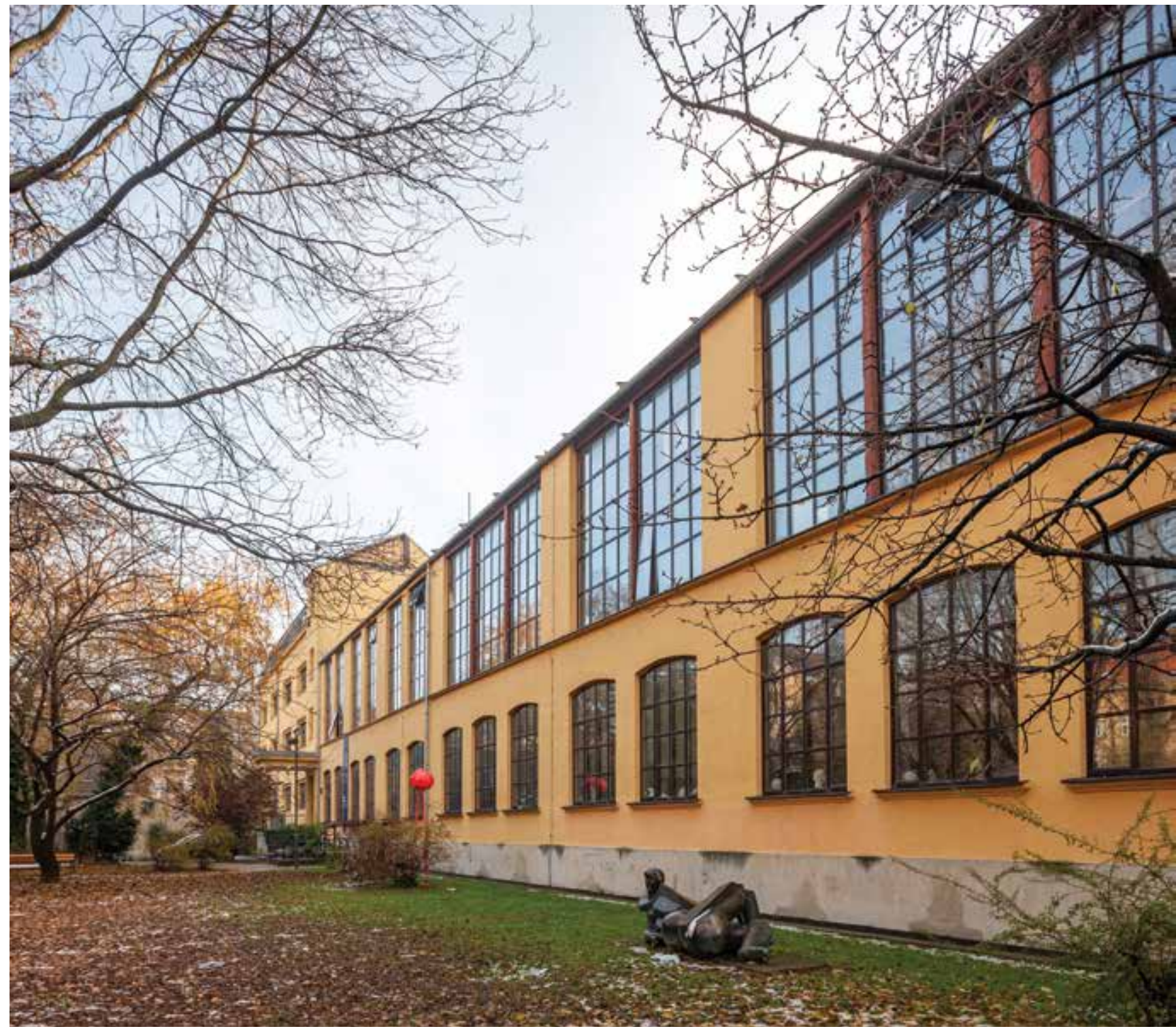

1. Akademija likovnih umjetnosti u Zagrebu, u prvom planu Umjetnički atelijeri Hermana Bolléa (foto: Paolo Mofardin, 2020.) Academy of Fine Arts in Zagreb, in the front of the picture are Art Studios designed by Herman Bollé

\section{Realizirana gradnja}

\section{Umjetnički atelijeri Hermana Bolléa}

Prvotno zdanje današnjeg sklopa Akademije likovnih umjetnosti čine Umjetnički atelijeri, podignuti na krilima jedne poticajne ere umjetničkih potreba i afirmacije likovne kulture u Zagrebu posljednjih desetljeća 19. stoljeća, koja je rezultirala osnivanjem temeljnih institucija važnih za razvoj cjelokupne umjetničke infrastrukture: Društva umjetnosti (1868.), Strossmayerove galerije starih majstora (1884.), Obrtne škole (1880.), Muzeja za umjetnost i obrt (1882.) te Umjetničkog paviljona (1898.).

Ugovorom između Kraljevskog zemaljskog erara i Društva umjetnosti ${ }^{5}$ određeno je mjesto za gradnju atelijera na državnom zemljištu na Prilazu, koje je pripadalo Primaljskom učilištu i Zavodu za odgoj gluhonijeme i slijepe djece. ${ }^{6}$ Prostrana unutrašnjost bloka - koji je većim dijelom formiran krajem 19. stoljeća, a omeđuju ga Ilica, Kačićeva ulica, Primorska ulica i Prilaz ${ }^{7}$ - određena je kao lokacija za izgradnju Umjetničkih atelijera. Sjeverna strana, orijentirana prema Ilici, od toga je vremena ostala gotovo nepromijenjena jer se većim dijelom parcele proteže zgrada Zavoda za odgoj gluhonijeme i slijepe djece, ${ }^{8}$ dok je susjedna parcela sa zapadne strane slobodna. Blok je krajem 19. stoljeća tek rahlo izgrađen jer će se kuće u Prilazu, koji povezuje Rudolfove vojarne sa Sveučilišnim (Kazališnim) trgom, početi intenzivnije podizati nakon 1890-ih godina. S južne, nasuprotne strane Umjetničkih atelijera 1910. godine podignute su u Prilazu tri reprezentativne stambeno-najamne kuće Hrvatske banke za promet nekretninama (kbr. 42, 44, 46), prema projektu Rudolfa Lubynskog, a dijagonalno prema jugozapadu u isto vrijeme Viktor Kovačić gradi crkvu sv. Blaža.

Pretpostavljamo da su nacrti nastali tijekom 1894. godine jer već Banska naredba br. $1616,{ }^{9}$ od 31. siječnja 1895 . godine predviđa izgradnju šest atelijera, četiri velika i dva manja prema projektu Hermana Bolléa. ${ }^{10}$ Građevinska dozvola za 

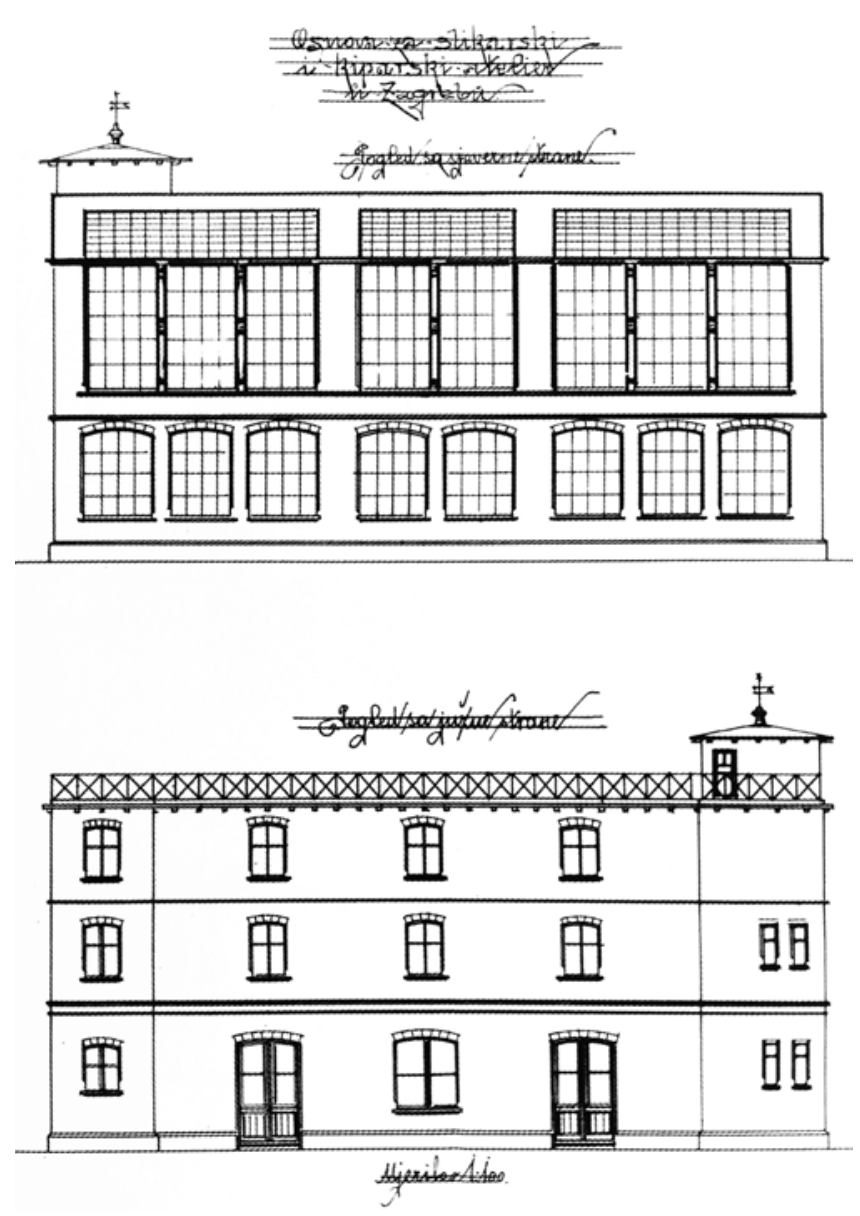

2. Herman Bollé, Osnova za slikarski i kiparski atelier u Zagrebu, 1894./95., pogled sa sjeverne strane, pogled s južne strane (Državni arhiv u Zagrebu, Zbirka građevnih nacrta)

Herman Bollé, Plan for a Painting and Sculpture Studio in Zagreb, 1894/95; view from the north, view from the south

gradnju kiparskoga i slikarskog atelijera izdana je 12. svibnja 1895. godine, a potpisao ju je gradonačelnik Adolf Mošinsky. ${ }^{11}$ Gradnja je tekla vrlo brzo te su već ujesen 1895 . godine umjetnici dobili atelijere na raspolaganje. Atelijeri su predani na uporabu Društvu umjetnosti na neodređeno vrijeme sa svrhom da se prostori dodijele umjetnicima, a Društvo je upravljanje povjerilo Upravi umjetničkih atelijera. ${ }^{12}$ Prvi atelijeri bili su dodijeljeni Vlahi Bukovcu, Mati Celestinu Medoviću, Ivanu Tišovu, Beli Čikošu, Otonu Ivekoviću i Robertu Frangešu, koji su zahvaljujući Kršnjaviju bili angažirani na brojnim državnim narudžbama za umjetničko opremanje javnih ustanova, poglavito Odjela za bogoštovlje i nastavu u Opatičkoj $10 .{ }^{13}$

Zgrada Umjetničkih atelijera smještena je u središtu parcele, na zemljištu površine $300 \mathrm{~m}^{2}$. Jednostavni, pravokutno koncipirani oblik jednokatne građevine na sjevernoj strani gotovo je u potpunosti ispunjen velikim ostakljenim površinama, po tri prozora s lijeve i desne strane kroz dvije etaže, te po dva u sredini. Otvori prizemlja nadvijeni su plitkim segmentnim lukovima, dok su na katu predviđeni viši prozori koji prelaze u zonu krova. Južna (stražnja) strana razdijeljena je horizontalno na tri dijela sa po četiri manja prozora i dvoja vrata ponad kojih se ponavlja motiv luka s pročelja. Krajnji bočni istaci na južnoj strani zgrade predviđeni su za stubišta, te sanitarni čvor u prizemlju lijevo i dvije sobice "za slugu « na katu. Tlocrt drugoga kata uz atelijere na sjevernoj strani predviđa i "sobe za umjetnike« s južne strane. ${ }^{14}$ Srednji, površinom nešto manji atelijeri imali su ugrađenu galeriju, do koje se dolazilo drvenim stubama.

Ulaz u zgradu bio je sa zapadne bočne strane. Do ulaza vode betonske stube, te se pretpostavlja da je to bio glavni ulaz, premda je Bollé predvidio i dvoja vrata sa stražnje strane. Ti su ulazi neosporno bili potrebni zbog unošenja materijala za kiparske atelijere, predviđene u prizemlju. Prostorije su na uglovima konstrukcijski ojačane koso položenim drvenim gredama, dok su atelijeri za slikare na katu sezali u otvoreno i dijelom ostakljeno krovište. ${ }^{15} \mathrm{~S}$ južne strane bila je predviđena i terasa s ogradom od kovanog željeza, na koju se izlazilo iz malog tornja. Jedini ukras na jednostavnom pročelju bili su lučni nadvoji od fasadnih opeka nad prozorima u prizemlju sjeverne strane i svim prozorima i vratima na južnoj strani, te drveni stupovi koji simetrično dijele velike atelijerske prozore na prvom katu. Glavni akcent oplošja zgrade su upravo rešetkasti prozori velikih dimenzija, koji ujedno i služe primarnoj svrsi atelijerskog prostora i koji se u načelu postavljaju sa sjeverne strane kako bi osvjetljenje prilikom umjetničkog rada bilo ravnomjerno i ne prejako. U projektiranju Umjetničkih atelijera Herman Bollé mogao se osloniti na iskustvo stečeno pri projektiranju radionica na sjevernom traktu monumentalne zgrade Obrtne škole, dovršene 1891. godine. Što se tiče njezinih velikih staklenih površina, varirao je motiv "staklenih stijena podijeljenih na tri dijela vitkim drvenim, djelomično raščlanjenim klasicizirajućim stupovima «, koje je izveo četrnaest godina ranije na Stakleniku za zimsko čuvanje egzotičnog bilja (Oranžeriji) u vrtu zagrebačkoga Nadbiskupskog dvora, 1881./1882. godine. ${ }^{16}$

Premda je zgrada projektirana vrlo jednostavno i u osnovi pročišćeno, slijedeći tek svoju namjenu umjetničkih radnih prostora, na njoj je bio prisutan još jedan prepoznatljiv Bolléov dekorativni detalj - gromobran u obliku zastavice postavljen na vrh tornjića, koji je zgradi davao slikovit historicistički izgled i pečat njezina arhitekta. Iz današnje perspektive možemo zaključiti da je pri prvoj dogradnji 1907. godine uklonjen dekorativni toranj, te da krov na sjevernoj strani nema ostakljene dijelove vidljive u nacrtu. Također više ne postoje ni ukrasni lučni nadvoji od fasadne opeke iznad prozora i vrata, čime su izgubljeni karakteristični stilski elementi prepoznatljivi za Bolléov historicizam. Od prvobitne opreme i dekoracije zgrade sačuvana je ograda rukohvata od kovanog željeza s florealnim motivom na prvom katu stubišta sa zapadne strane, vrlo vjerojatno izrađena prema nacrtu Hermana Bolléa u Obrtnoj školi. ${ }^{17}$

Gradnju je izveo Kuno Waidmann, koji je već prije surađivao s Bolléom. Novopronađeni dokument u Hrvatskome državnom arhivu navodi da je u gradnji atelijera sudjelovalo i građevinsko poduzetništvo Pilar, Mally \& Bauda. ${ }^{18}$

Zgrada Umjetničkih atelijera imala je od samog početka visok standard građevinske infrastrukture. Bila je spojena na 


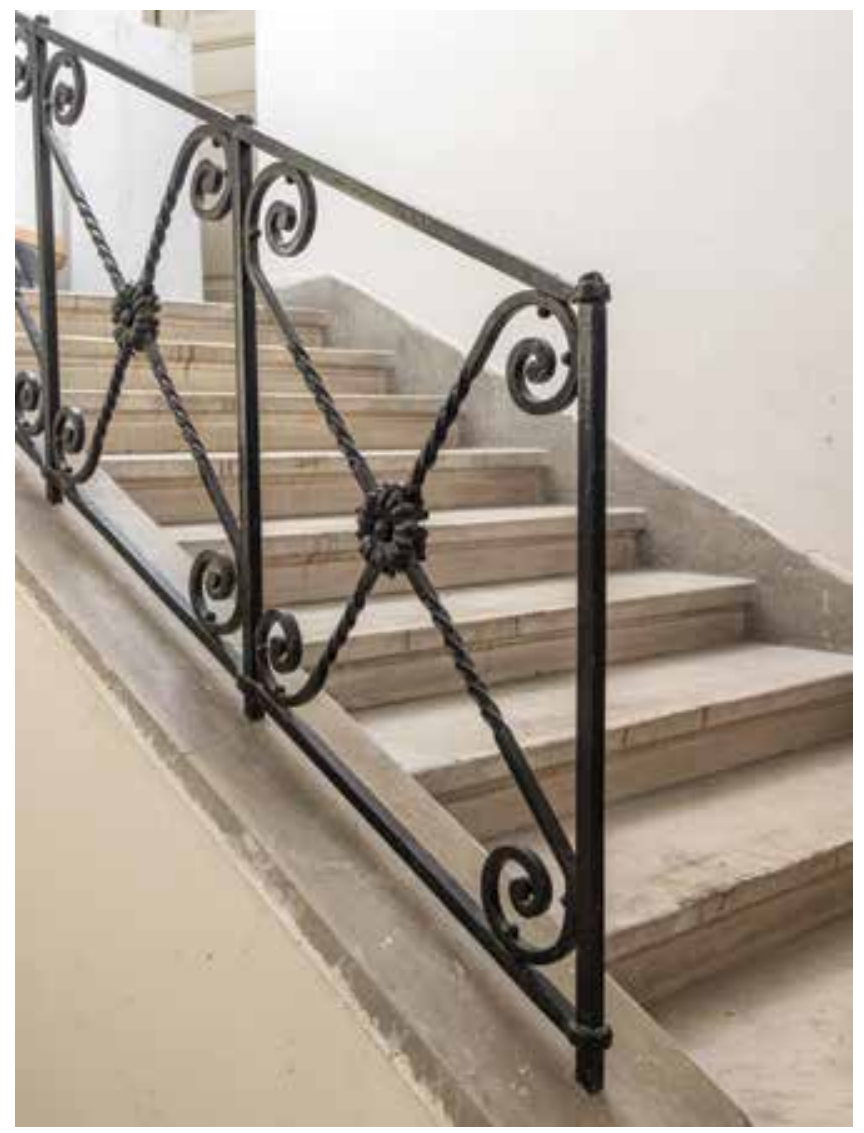

3. Ograda stubišta prema zamisli Hermana Bolléa (foto: Paolo Mofardin, 2020.)

Staircase railing designed by Herman Bollé

novi dovod vodovoda s Prilaza, a vodovodnu je mrežu izveo "građevni limar i uvađač vodovoda « A. Maruzzi. Iz Pohvale za Umjetničke atelijere na završetku gradnje ${ }^{19}$ doznajemo da je tvrtka Wilhelm Brückner iz Beča izvela projekt centralnoga grijanja s parom na visoki tlak, te da je željeznu konstrukciju ostakljenog krova izvela tvrtka Wagner, također iz Beča. ${ }^{20}$ Tesarske radove izvela je tvrtka Herz i drug, a stolarske, koji uključuju unutrašnje uređenje atelijera, drvene galerije i namještaj, stolari Đuro Blažeković, Albert Zorinić, Ivan Oblak, Antun Kontak i Josip Šeremet, ${ }^{21}$ te tvrtka Bothe i Ehrmann. Tapetarske radove izveo je tapetar Tauchman, a zavjese je izradio Šteger. Sveukupni troškovi atelijera iznosili su 43956 kruna. $^{22}$

Naredbom Zemaljske vlade od 19. travnja 1896. godine dozvoljen je kredit od 3630 kruna "za uređenje dvorišta i vrta kod novogradnje umj. ateliera«, koje je već bilo predviđeno na Bolléovu položajnom nacrtu koji planira zavojite staze oko rondele sa sjeverne i parkovnu površinu s južne strane zgrade umjetničkih atelijera. ${ }^{23}$ Hortikulturni radovi, iskop, niveliranje, dovoz humusa, uređenje nasada te sve vrtlarske radnje povjeravaju se Vitězslavu Durcháneku. ${ }^{24}$ Prema Kršnjaviju, u vrtu oko atelijera posađene su voćke: »da u proljeće bude motiva za slikanje, a u jesen što za jesti «. ${ }^{25}$

Ubrzo nakon izgradnje, brojni umjetnici traže prikladan prostor za svoj rad i mole da im se ustupi atelijer ili polovica atelijera. ${ }^{26}$ Uviđa se i da šest radnih prostora nije dovoljno za potrebe domaće umjetničke produkcije, te Uprava umjetničkih atelijera od samog početka upozorava na potrebu proširenja zgrade. ${ }^{27}$ Premda su u početku građeni sa svrhom dodjele prikladnoga radnog prostora umjetnicima koji će odrađivati poslove po narudžbi Odjela za bogoštovlje i nastavu i Društva umjetnosti, s vremenom prerastaju i prostorno i koncepcijski u višu umjetničku školu, nadograđujući okvir obrazovanja koji je nudila Obrtna škola, smještena tek nekoliko blokova istočno.

\section{Dogradnja Victora Grossa}

Usporedno s osnutkom Više škole za umjetnost i umjetni obrt 1907. godine, graditelj Victor Gross izrađuje nacrte za prvu veliku dogradnju, ${ }^{28}$ pa desetak godina nakon izgradnje prvih šest atelijera, zgrada dobiva nastavak s istočne strane na koju se naslanja i krilo prema južnoj strani parcele.

Prateći osnovnu strukturu postojeće građevine, Gross dograđuje novu zgradu prema istoku u potpunosti poštujući raniji Bolléov projekt. ${ }^{29}$ Novi su atelijeri prostorno nešto manji od Bolléovih, ali ponavljaju istu podjelu na tri atelijera u prizemlju i tri na prvom katu, što je razvidno na prozorskim osima sjevernog pročelja. Ponavljaju se po tri para simetrično postavljenih međusobno odvojenih prozora bez ukrasa, te je jedina razlika u tome da su na Bolléovu (zapadnom) dijelu prozori atelijera prvog kata spojeni i vizualno razdijeljeni tankim drvenim gredama. Budući da je Herman Bollé u to vrijeme bio i dalje aktivan, možemo pretpostaviti da je u osnovnoj ideji dogradnje poštivan njegov prvobitni projekt Umjetničkih atelijera, a da je Gross uključen s namjerom da realizira nadogradnju bez većih autorskih invencija. Kasnija unificirana fasada zgrade i promjena pokrova gotovo su potpuno izjednačili te dvije građevine. ${ }^{30}$

Sačuvani Grossovi nacrti razrađuju dogradnju podruma, prizemlja i prvog kata. Podrum je izveden duž cijele zgrade i pokriven pruskim svodom. Prizemlje se sastoji od triju prostornih jedinica s ulazima iz hodnika, a svaka je podijeljena na po dvije manje prostorije, vjerojatno kako bi se dobilo šest atelijerskih prostora. Takva podjela nije u konačnici realizirana, nego je ponovljena izvedba sa po tri velika atelijera u prizemlju i na katu. U zahvatu došlo je i do nekoliko nužnih izmjena, probijanja vrata kao poveznice stare i nove zgrade, dodavanja sanitarnog čvora te izgradnje novog stubišta s istočne strane. Premda u nacrtima nije dokumentiran, istodobno se gradi i južni aneks, čime se dobiva novi prostor za kiparske radionice. ${ }^{31}$ Ta se prizemnica užim dijelom prislanja na sjevernu, glavnu zgradu, pa je njezina osnovna orijentacija istok-zapad. Veliki rešetkasti atelijerski prozori postavljeni su sa zapadne strane i ponavljaju isti blagi lučni nadvoj kao i prozori prizemlja glavne zgrade. Iz dokumenta koji Hrvatska vjeresijska banka upućuje Odjelu za bogoštovlje i nastavu, ${ }^{32}$ saznajemo da je betonske radnje na novogradnji izveo poznati zagrebački građevni inženjer Josip Dubsky. ${ }^{33}$

Projekt dogradnje 1907./1908. godine u konačnici je znatno povećao cjelokupni prostor te je Umjetničke atelijere prilago- 


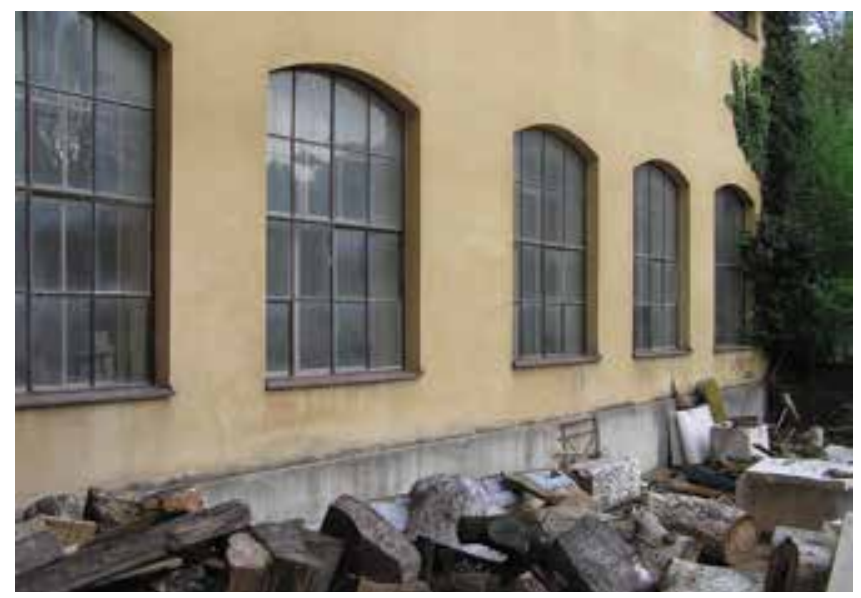

4. Fasada južne dogradnje izvedene prema projektu Victora Grossa, 1908., prizemlje prije obnove (foto: Aleksander Laslo, Grad Zagreb, Gradski zavod za zaštitu kulturne i prirodne baštine, 2004.)

Façade of the south extension, designed by Victor Gross, 1908, groundfloor, before the renovation

dio potrebama Umjetničke škole. ${ }^{34}$ Zasluge za njezin osnutak i dogradnju postojećih atelijera pripadaju kiparu Robertu Frangešu i tadašnjem odjelnom predstojniku Milanu Rojcu. U povećanoj zgradi mogla se proširiti i nastavna obuka, te se moglo upisati Slikarski odjel, Kiparski odjel i Odjel za kandidate učitelja risanja, a uvedena je i obuka iz grafike. Od nastavničkog kadra 1907. godine Višoj školi dodijeljeno je nekoliko profesora umjetničkih predmeta koji su radili na Obrtnoj školi. Robert Frangeš postaje upravitelj, a Branko Šenoa tajnik. Risanje i slikanje preuzimaju Menci Klement
Crnčić, Bela Čikoš Sesija i Oton Iveković, a godinu dana kasnije pridružuju se Rudolf Valdec i Robert Auer. ${ }^{35}$

Geneza i tradicija škole ukorijenjeni su u već uhodanom modelu Obrtne škole sa sve većom emancipacijom slikarskih nastojanja Crnčića i Čikoša, te kiparskih Frangeša i Valdeca. Kršnjavijeva svrha gradnje Umjetničkih atelijera u pravom je smislu oživjela u Višoj školi jer su njeni učenici i profesori nastavili raditi narudžbe za umjetničko opremanje javnih zgrada, posebice tada aktualan zahtijevan posao ukrašavanja Kraljevske sveučilišne knjižnice 1911./12. godine.

\section{Prigradnja nove zgrade Ćirila Metoda Ivekovića}

Bolléova i Grossova zgrada dobiva treće proširenje neposredno nakon Prvoga svjetskog rata, kada se škola reformira i dobiva naziv akademije, a uvođenjem novih programa ponovno se javlja potreba za povećavanjem prostora. Prigradnja istočnog aneksa započinje 1921. godine. Dvokatnicu s mansardom, koja se izravno naslanja na Grossov produžetak prvih Bolléovih umjetničkih atelijera, projektira arhitekt Ćiril Metod Iveković. ${ }^{36} \mathrm{U}$ Arhivu Akademije likovnih umjetnosti čuvaju se originalni arhitektonski nacrti, građevinski dnevnici, završni računi i sva dokumentacija povezana s tom gradnjom, koja se ovdje prvi put objavljuje. ${ }^{37}$ Tim povećanjem dobiva se današnji izgled sjevernog pročelja kao reprezentativne zgrade sa središnjim glavnim ulazom i visokom dvokatnom konstrukcijom s mansardom, koja se prislanja na prethodno građene jednokatne atelijere.

Moguće je da su Ivekovića preporučili Robert Frangeš, njegov bivši učenik u Obrtnoj školi, a tada upravitelj Više škole, i brat, slikar Oton Iveković. Arhitekt Iveković dotad nije rea-

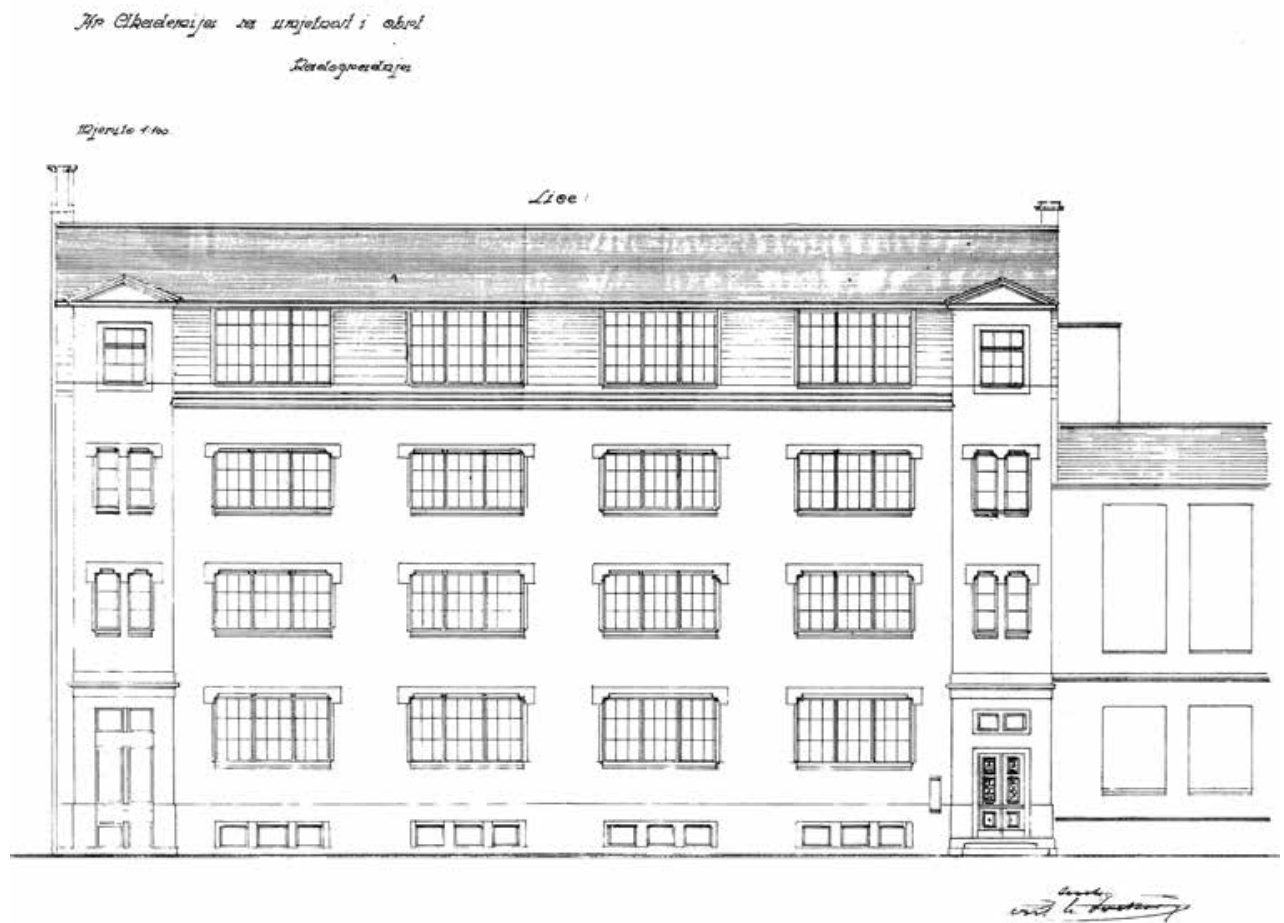

5. Ćiril Metod Iveković, Kr. Akademija za umjetnost i obrt. Nadogradnja, 1921. (Arhiv Akademije likovnih umjetnosti, fond Građevinska dokumentacija ALU)

Ćiril Metod Iveković, draft for the extension of the Royal Academy of Arts and Crafts, 1921 


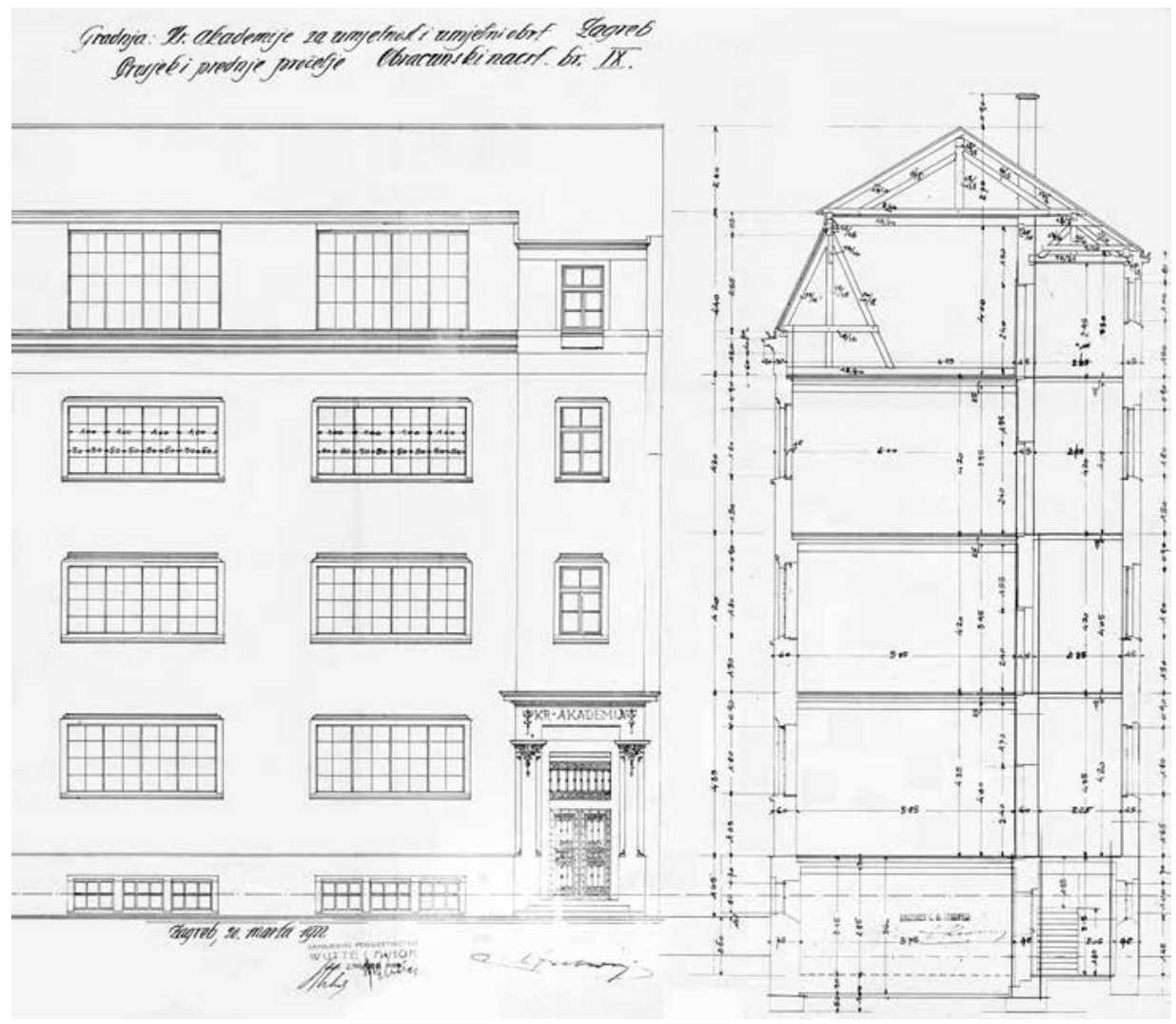

6. Ćiril Metod Iveković, Gradnja Kr. akademije za umjetnost i obrt. Prosjek i prednje pročelje, Obračunski nacrt br. IX, Zagreb, 22. marta 1922. (Arhiv Akademije likovnih umjetnosti, fond Građevinska dokumentacija ALU)

Ćiril Metod Iveković, Construction of the Royal Academy of Arts and Crafts, cross-section and front façade, calculation draft no. IX, Zagreb, March 22, 1922

lizirao niti jedan sličan projekt jer se bavio uglavnom sakralnom gradnjom, sudbenim palačama i vijećnicama. Izvedbu preuzima građevinsko poduzeće Wutte i Mihok. Riječ je o manje poznatom zagrebačkom graditelju Stjepanu Wutteu koji je završio Graditeljsku školu i potom kao samostalni graditeljski poduzetnik projektirao i izvodio obiteljske kuće i trgovačko-stambene zgrade. ${ }^{38}$ Slavko Mihok je neko vrijeme surađivao s Wutteom, a potom is Ottom Goldscheiderom. ${ }^{39}$ U vrijeme treće, Ivekovićeve faze dogradnje kompleksa, prvi projektant Umjetničkih atelijera Herman Bollé još je uvijek prisutan u Zagrebu (umire 1926. godine).

Iz građevinskog dnevnika Prigradnje Kraljevske akademije za umjetnost $i$ umjetni obrt saznajemo da su radovi započeli 27. kolovoza 1921. godine, a 9. rujna postavljen je temeljni kamen. ${ }^{40}$ Najprije se pristupilo iskopu budućeg podruma i izravnavanju terena, te betoniranju temelja. U prosincu iste godine probijen je otvor između stare i nove zgrade, na pod se počinje postavljati bijeli terrazzo s crnom bordurom, koji se i danas nalazi u hodnicima Akademije, ${ }^{41}$ a sačuvana

7. Ćiril Metod Iveković, Kr. akademija za umjetnost i obrt. Nadogradnja II. kat, 1921.(Arhiv Akademije likovnih umjetnosti, fond Građevinska dokumentacija ALU)

Ciril Metod Iveković, design for the extension of the Royal Academy of Arts and Crafts, plan of the second floor, 1921

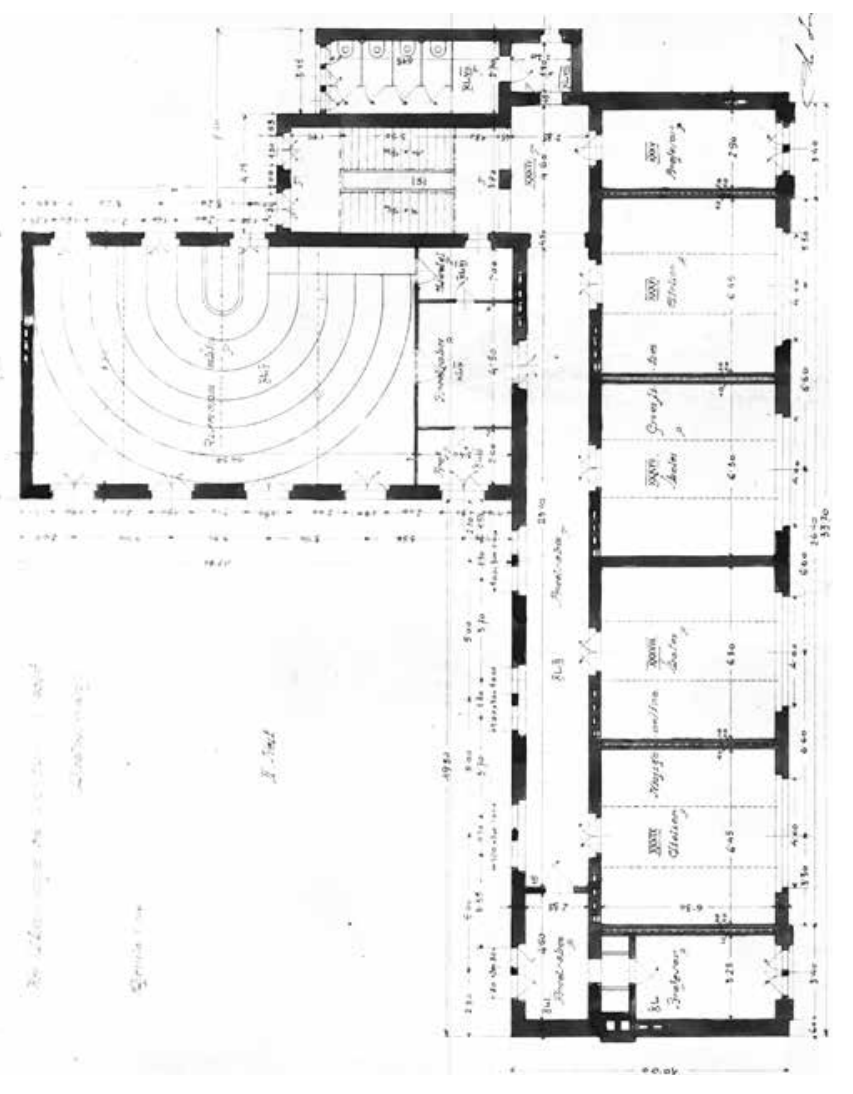




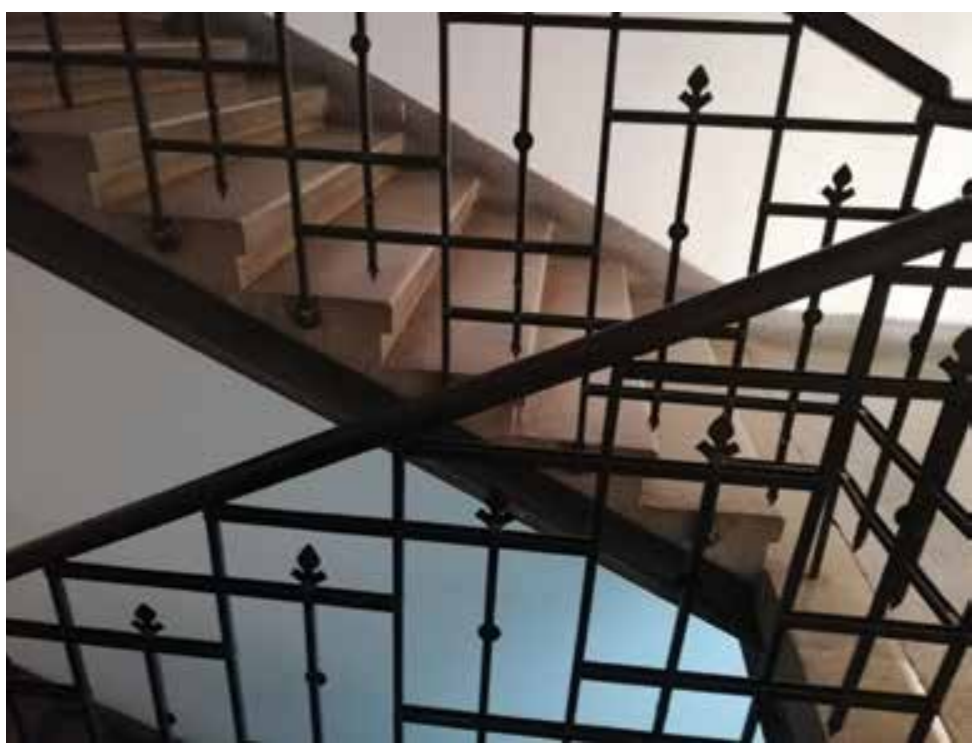

8. Stubište s ogradom u Ivekovićevoj zgradi (foto: Irena Kraševac, 2020.)

Staircase with railing in Iveković's building

je i metalna ograda stubišta. U izvedbi su sudjelovali brojni zagrebački obrtnici, a u zaključnom obračunu navedeno je da je za dogradnju ukupno potrošeno 1,101.520 dinara. Krovopokrivačke radove izveli su obrtnici Bauer i Heinz, limarske i vodovodne Maruzzi i Štaudar, a ličilačke Leopold Murk. Dom - dioničko društvo za drvene gradnje izvelo je sve tesarske radove (vrata, prozore i podove).

Cijelo vrijeme gradnje, uz arhitekta Ivekovića, radove je nadgledao kuratorij Zaklade za unutarnje uređenje Kraljevske akademije za umjetnost i umjetni obrt, sastavljen od članova profesorskog zbora - Tomislava Krizmana, Joze Kljakovića, Vojte Braniša, Ljube Babića, Roberta Frangeša, Ferde Kovačevića, Branka Šenoe, Ive Kerdića, Bele Čikoša i Ivana Meštrovića.

Prvobitni nacrt pročelja razlikuje se u detaljima od izvedenog. Arhitekt Iveković zamislio je na rubovima uz glavni kubus zgrade s lijeve i desne strane plitke istake na fasadi koji uskim prozorima naglašavaju glavni i sporedni ulaz.
Zgrada je koncipirana simetrično, sa po četiri pravokutna atelijerska prozora na svakoj etaži i krovnim prozorima na mansardi. Iveković je svojom prigradnjom skladno povezao prostor glavne zgrade s prijašnjim prostorima Umjetničkih atelijera. Bez puno dekorativnih elemenata, ponavljajući uzorak pravilno izmjenjujućih prozora, te poštujući zadane arhitektonske elemente prijašnjih gradnji, zgrada Akademije u svom sjevernom pročelju danas djeluje kao jedinstveno građeni korpus.

Ulazna vrata su također drukčije oblikovana nego na nacrtu. ${ }^{42}$ Masivne drvene vratnice sa secesijskim ukrasom zaštitne ograde od kovanog željeza vješto su uklopljene u okvir fasade klasičnog sloga s vijencem ispod kojeg se nalazio naziv ustanove. Tim elementima klasične arhitekture arhitekt je naglasio funkciju javne ustanove.

Godine 1925. s iličke strane izgrađena je reprezentativna zidana ograda s vratnicama od kovanog željeza s motivom izdužene $S$-volute, koja je u cijelosti sačuvana i obnovljena 2006. godine. Nacrt za ogradu izradio je Jaroslav Albert koji je zajedno s Milanom Pollakom i Julijem Bornsteinom bio partner u poznatom zagrebačkom građevinskom poduzeću Pollak - Albert - Bornstein. ${ }^{43}$ Time je definiran sjeverni ulaz u perivoj koji vodi do zgrade Akademije.

\section{Moderna zgrada Ive Geršića}

Neposredno nakon Drugoga svjetskog rata razmišljalo se o gradnji još jedne zgrade Akademije na nekoliko različitih lokacija, Radoševićevu bregu, Koturaškoj cesti, Borongajskoj cesti ili u Ksaverskoj dolini, a posebno je bila zanimljiva ideja da se zgrada Akademije podigne u sklopu Studentskoga grada.

Iz dopisa upućenog 1956. godine Državnom sekretarijatu za poslove narodne privrede, saznajemo da je prigradnja zgrade Akademije likovnih umjetnosti neophodna zbog povećanja broja studenata, te da Akademija već godinama koristi u nastavne svrhe prostorije bivšeg Starčevićeva doma i prostorije na Jezuitskom trgu. ${ }^{44}$

Do treće dogradnje dolazi potkraj mandata rektora Frane Kršinića i tijekom mandata Vanje Radauša ${ }^{45}$ Odbor za

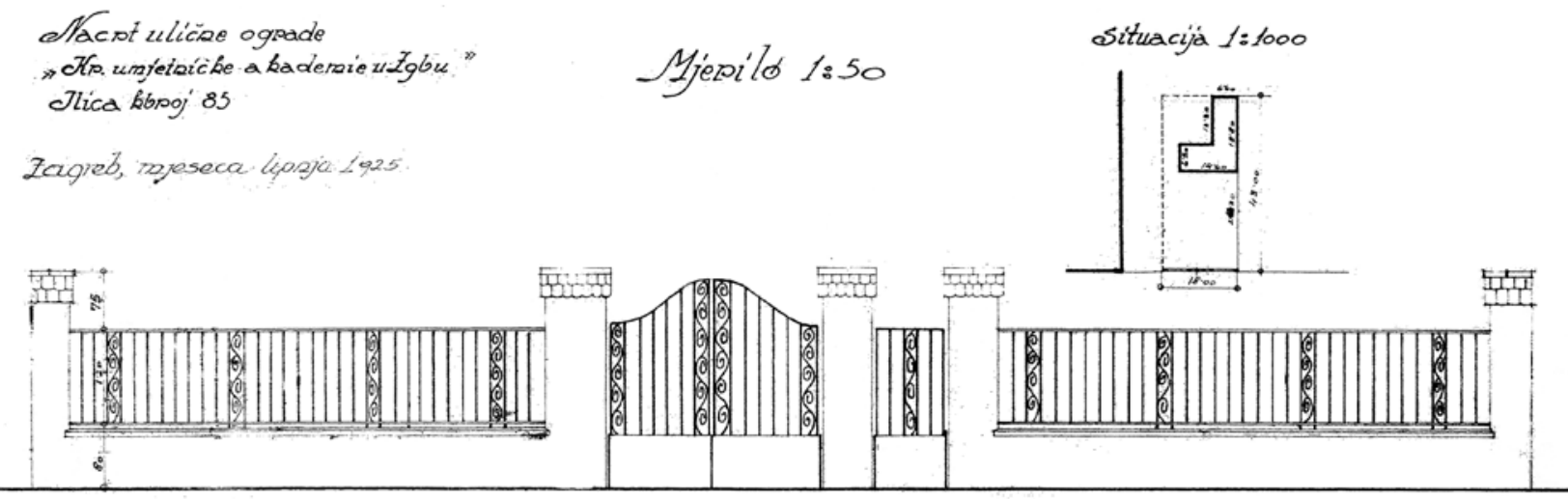

9. Jaroslav Albert, Nacrt ulične ograde Kr. umjetničke akademije u Zagrebu, 1925. (Državni arhiv u Zagrebu, Zbirka građevnih nacrta) Jaroslav Albert, draft of the street fence at the Royal Academy of Arts in Zagreb, 1925 


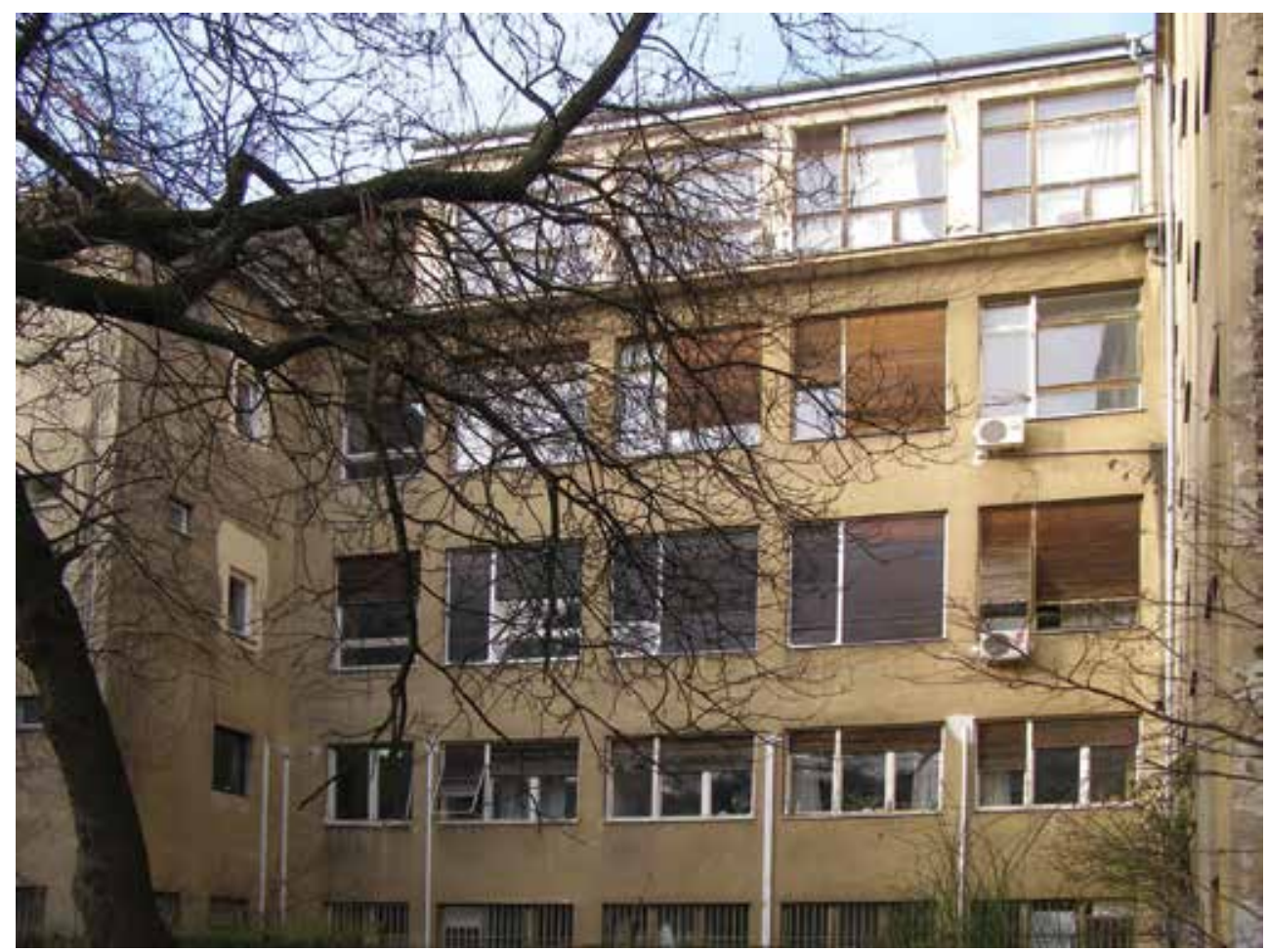

10. Jugoistočno krilo Akademije likovnih umjetnosti izgrađeno prema projektu Ive Geršića, 1957. (Grad Zagreb, Gradski zavod za zaštitu kulturne i prirodne baštine, 2010.)

Southeast wing of the Academy of Fine Arts built upon the design of Ivo Geršić in 1957

prigradnju Akademije aktivno je sudjelovao u svim fazama gradnje, a činili su ga profesori Antun Augustinčić, Drago Ibler, Sigo Summerecker, Ivo Režek, Vanja Radauš, Andro Vid Mihičić, Marijan Detoni, Frano Kršinić, Ljubo Babić, Dragan Beraković, te tadašnji tajnik Akademije Luko Bradarić. ${ }^{46}$

Godine 1954. pristupa se prigradnji novog objekta, trokatnoga isturenog krila s jugoistočne strane ukupne površine oko $2000 \mathrm{~m}^{2}$ koji se bočno naslanja na postojeću Ivekovićevu zgradu iz 1921., s namjerom da se funkcionalno projektiraju prostorije prema potrebama suvremeno koncipirane nastave praktičnih i teorijskih predmeta. Gradnja je s prekidima trajala do 1957. godine, a u isto su vrijeme adaptirani glavni ulaz, sanitarni čvorovi i slikarski atelijeri u postojećem objektu. ${ }^{47}$ Projektant i voditelj gradnje bio je Ivo Geršić, arhitekt specijaliziran za izgradnju školskih i zdravstvenih ustanova ${ }^{48}$ a gradnju je izvelo građevinsko poduzeće Novogradnja iz Zagreba.

U visokom prizemlju smještene su sve prostorije za upravu i administraciju, čime Akademija od svog osnutka prvi put dobiva prostorije za tu namjenu. Također je u produžetku prizemlja izgrađena nova, prostrana akt-sala s dnevnom i umjetnom stropnom rasvjetom i odvojenim garderobama za modele i studente, te vijećnica. Na prvom i drugom katu su kabineti za profesore teorijskih predmeta te velika i mala predavaonica s prozorima na istočnoj strani. Takvu je dispoziciju uvjetovala veličina raspoloživog zemljišta za gradnju, kao i smještaj stubišta u postojećem objektu. Raznolika namjena prostora na etažama iziskivala je armiranobetonski konstruk-

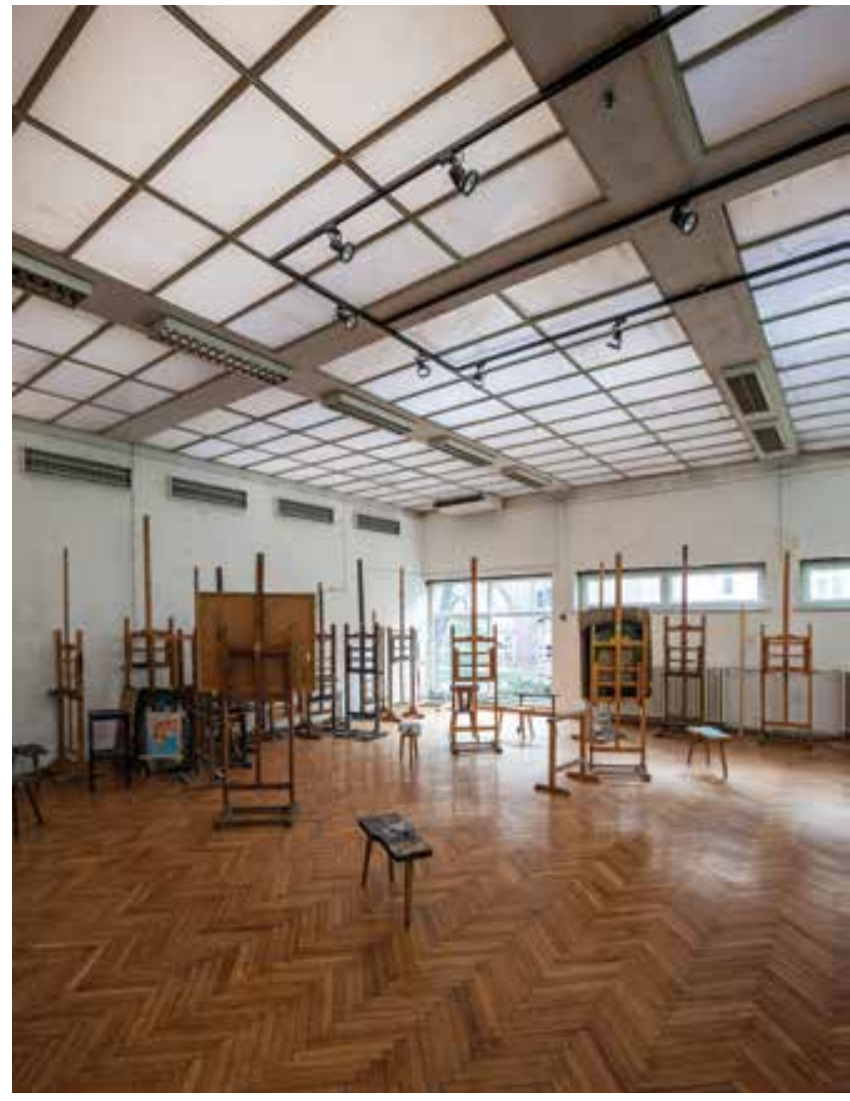

11. Akt-sala s ostakljenim stropom u Geršićevoj zgradi (foto: Paolo Mofardin, 2020.)

Hall for nude painting with glass ceiling in Geršićs wing 


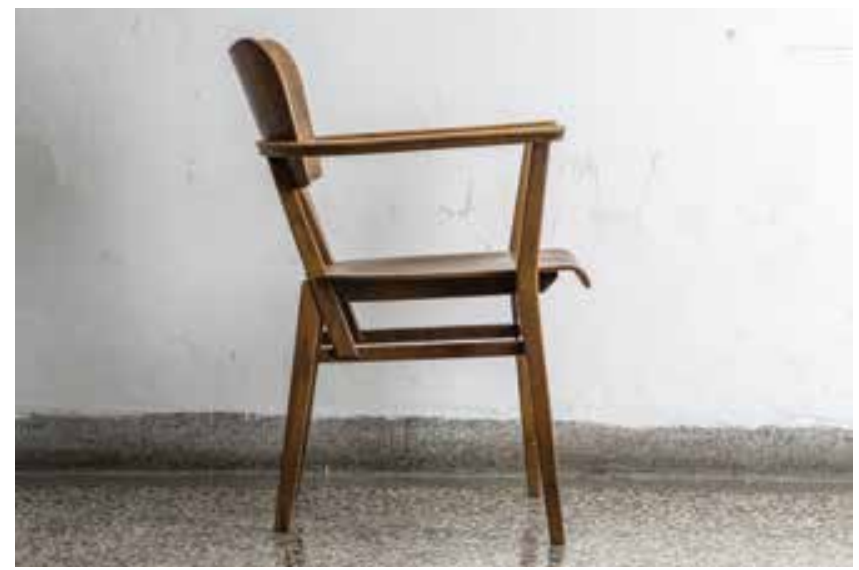

12. Naslonjač prema nacrtu Fanike Bihler iz Vijećnice Akademije likovnih umjetnosti (foto: Paolo Mofardin, 2020.)

Armchair designed by Fanika Bihler from the Meeting Hall of the Academy of Fine Arts

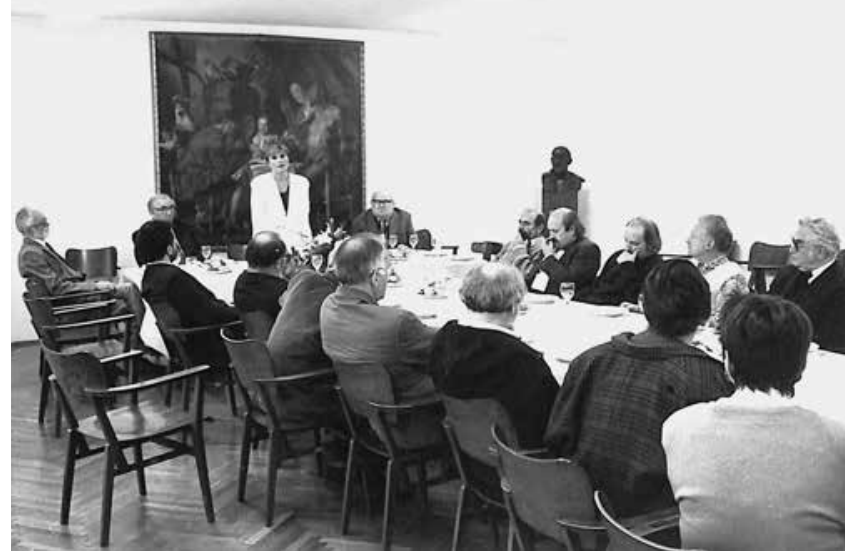

13. Vijećnica Akademije likovnih umjetnosti u Geršićevoj zgradi s namještajem prema projektu Fanike Bihler (Arhiv Akademije likovnih umjetnosti, 1997.)

Meeting Hall in the Geršićs wing of the Academy of Fine Arts with the funiture designed by Fanika Bihler
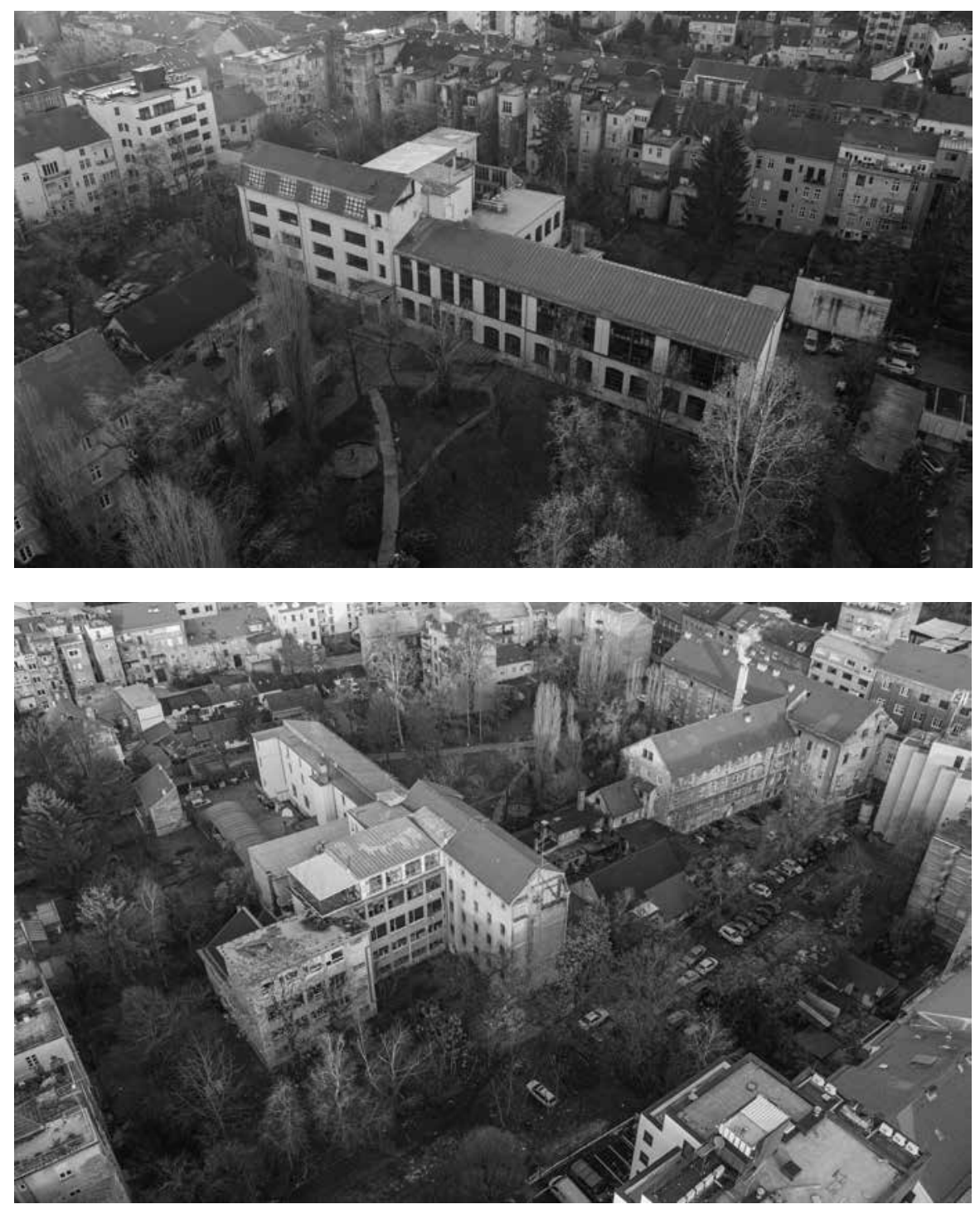

14. Blok s kompleksom zgrada Akademije likovnih umjetnosti u Zagrebu, pogledi iz zraka (foto: Paolo Mofardin, 2020.)

Aerial views of the building complex of the Academy of Fine Arts 


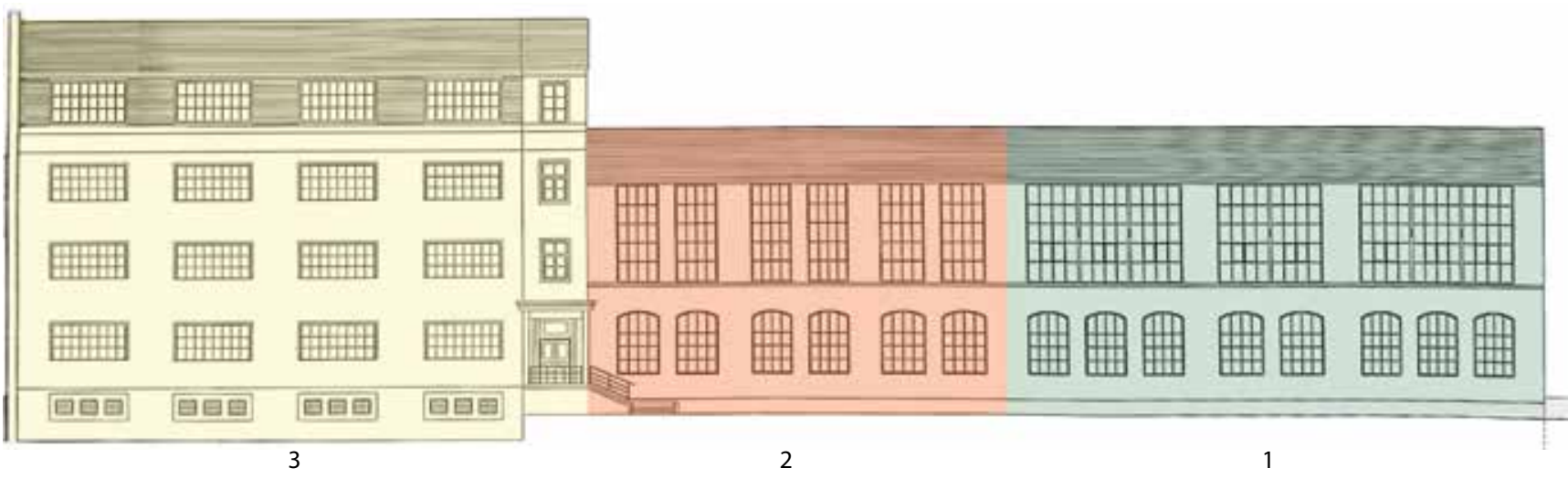

15. Sjeverno pročelje zgrade Akademije likovnih umjetnosti u Zagrebu, prikaz građevinskih faza, zdesna na lijevo: 1 - Herman Bollé (1895./1896.); 2 - Victor Gross (1907./1908.); 3 - Ćiril Metod Iveković (1921./1922.)

The north façade of the Academy of Fine Arts in Zagreb, the construction sequence: 1 - Herman Bollé (1895/96); 2 - Victor Gross (1907/08); 3 - Ciril Metod Iveković (1921/22)

tivni sustav, što je omogućavalo lakšu provedbu eventualnih kasnijih adaptacija. U suterenu je smješten grafički odsjek s prešama i litografska radionica, nakon čega je formalno osnovan Grafički odsjek 1956./57. godine.

Uz glavni arhitektonski projekt, naručen je i projektni elaborat za izradu namještaja upravnog trakta, administrativnih ureda, tajništvo, dekanat i vijećnicu, te veliku predavaonicu koja je ostala izvorno očuvana do danas. ${ }^{49}$ Elaborat je izradila Geršićeva suradnica, arhitektica Fanika Bihler. ${ }^{50}$ Projektom opreme za Upravni trakt prigradnje akademijine zgrade, Bihler je u skladu s potrebama naručitelja dizajnirala sav namještaj: stolove i stolice za novu vijećnicu, polunaslonjače i tapecirane naslonjače, tapecirane klupe, niske ormare za knjige, stolove i stolice za urede, te posebno masivne nepomične klupe za veliku predavaonicu. ${ }^{51}$ Namještaj je funkcionalan

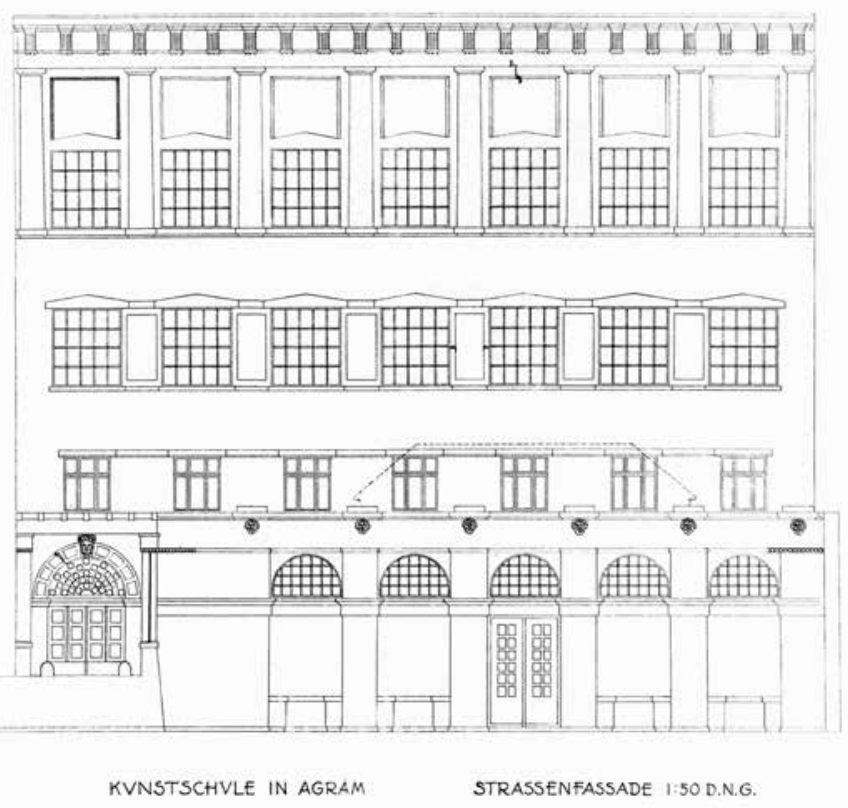

16. Projekt Umjetničke škole u Zagrebu, 1907./1908., nacrt ulične fasade (Ministarstvo kulture i medija RH, Uprava za zaštitu kulturne baštine, fond Kovačić-Ehrlich)

Design for the Art School in Zagreb, 1907/08, front façade i izrazito udoban, ergonomski oblikovan, jednostavnog i pročišćenog dizajna, izveden od kvalitetne hrastovine. ${ }^{52}$

Time je završena gotovo pola stoljeća duga gradnja zgrade Akademije likovnih umjetnosti, koja je u konačnici djelo nekoliko graditelja kroz više generacija, te se može navoditi kao kolektivno djelo Hermana Bolléa, Victora Grossa, Ćirila Metoda Ivekovića i Ive Geršića. Namjena građevine diktirala je maksimalnu arhitektonsku jednostavnost, bez suvišne dekoracije i stilskih varijacija. Takvu ju je prvotno projektom Umjetničkih atelijera zamislio Herman Bollé, pa su se na njega mogli nadovezati i ostali arhitekti, stavljajući u prvi plan ponajprije potrebe umjetnika za radnim prostorom. Reprezentativnost same arhitekture bila je podređena njezinoj namjeni, a to je potencirao i položaj zdanja u dubini parcele. Umjesto dekorativnog historicizma u stilu svoga

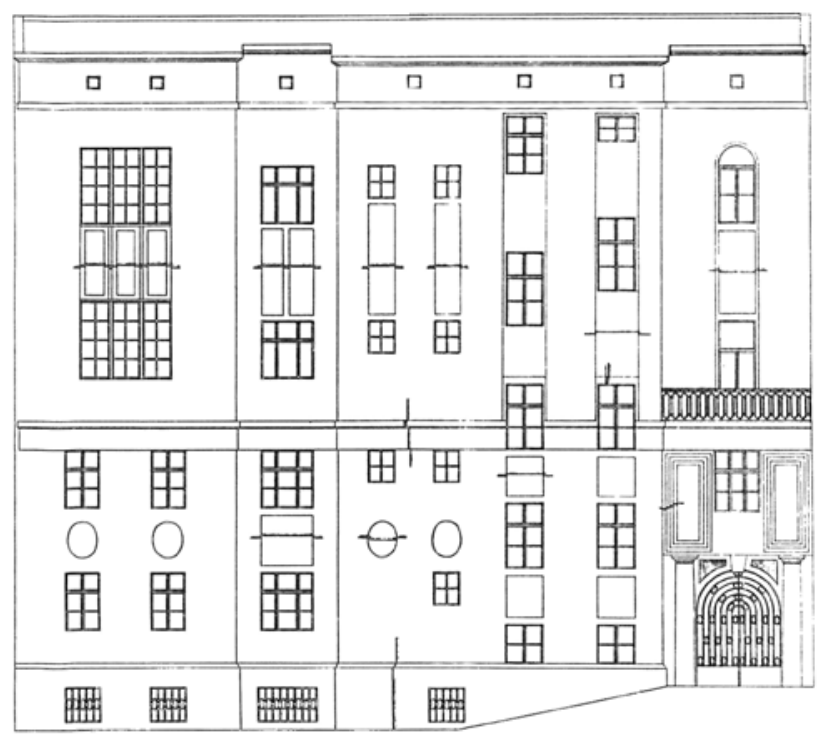

KVNSTSCHVLE IN AGRAM

HOF-FASSADE 1:50 D.N.G.

17. Projekt Umjetničke škole u Zagrebu, 1907./1908., nacrt dvorišne fasade (Ministarstvo kulture i medija RH, Uprava za zaštitu kulturne baštine, fond Kovačić-Ehrlich)

Design for the Art School in Zagreb, 1907/08, rear façade 
vremena, naglašena je pročišćenost oblikovanja i jednostavnost arhitekture prvih atelijera, pa su se zahvaljujući tome skladno nastavljale dogradnje i prigradnje u razdoblju od gotovo šezdeset godina. ${ }^{53}$

\section{Nerealizirani projekti}

U povijesti gradnje Akademije likovnih umjetnosti u Zagrebu, važno mjesto zauzimaju i zamišljeni, pripremljeni, ali nerealizirani projekti dogradnji i proširenja. Najcjelovitija projektna dokumentacija odnosi se na nacrte pripisane Viktoru Kovačiću koji se čuvaju u fondu građevne dokumentacije Kovačić-Ehrlich u Upravi za zaštitu kulturne baštine Ministarstva kulture i medija RH. Riječ je o 11 nacrta na ozalidima od kojih je jedan naslovljen Gradnja umjetničke škole u Zagrebu. Situacija, šest Gradnja škole za umjetnost u Zagrebu, a četiri Kunstschule in Agram..$^{54} \mathrm{Nacrti}$ nisu potpisani ni datirani, a objavila ih je Olga Maruševski atribuiravši ih Viktoru Kovačiću i datiravši ih u 1907./1908. godinu. ${ }^{55}$ Upravo je u isto to vrijeme bila realizirana prva (istočna) dogradnja Bolleóvih Umjetničkih atelijera prema nacrtu Victora Grossa.

Entuzijazam zbog osnutka Više škole i proširenja atelijerskih prostora bio je pokretač puno ambicioznijeg plana koji je uključivao gradnju nove zgrade i akademijske galerije na slobodnoj parceli na Ilici, zapadno od Zavoda za gluhonijeme. Dograđeni "stari" atelijeri nisu u potpunosti zadovoljavali ambiciozne planove upravitelja i nastavnika, te se razrađuje kompleksna zamisao sklopa koji uključuje izložbeni prostor u prizemnoj zgradi s povišenim i ostakljenim galerijskim krovom, glavnu zgradu s knjižnicom, školom za arhitekturu, te većim i manjim atelijerima. Nacrti s obrazloženjem koje su potpisali Crnčić i Šenoa upućeni su na Vladu 1909. godine. ${ }^{56}$ Plan se izjalovio jer nije dobio podršku Građevnog odsjeka, ${ }^{57}$ a Kovačić u konačnici nije prihvatio Frangešov poziv da u sastavu umjetničke pokrene i prvu arhitektonsku školu. ${ }^{58}$ Ostali su tek vrlo zanimljivi nacrti koji svjedoče o dalekosežnosti planiranja, te dostojanstvu i važnosti koju je Umjetnička akademija trebala imati u Zagrebu, pozicionirana u Ilici. Nepotpisani nacrti su i dalje predmetom atributivne dileme jer se ne spominju u dosadašnjim popisima nerealiziranih projekata ni Viktora Kovačića ni Huge Ehrlicha, premda postoje osnovane indicije da su plod te suradnje koja se intenzivirala upravo $\mathrm{u}$ to vrijeme. ${ }^{59}$

Ulično pročelje očišćeno je od suvišnih dekorativnih reminiscencija i glavni je naglasak na ravnoj plohi s pravilno raspoređenim velikim prozorima, koji orijentirani na sjevernu stranu odaju atelijerske prostore u unutrašnjosti. Prozori nisu uvučeni i obrubljeni dekorativnim aplikacijama, nego su dosljedno položeni u ravnini fasade. Plitki pilastri jednostavnih kapitela u zoni drugog kata, ritmički niz triglifa i metopa u zoni krovnog vijenca i aplikacije maskerona nad glavnim ulazom i u prizemlju, jedini su dekorativni elementi krajnje moderno koncipirane zgrade. Prizemni, galerijski dio raščlanjen je polukružnim lukovima, a glavni ulaz predviđen je kao kolni ulaz s istočne strane. Pročišćena koncepcija arhitekture s naznakama »klasičnog« modernizma, gradacija

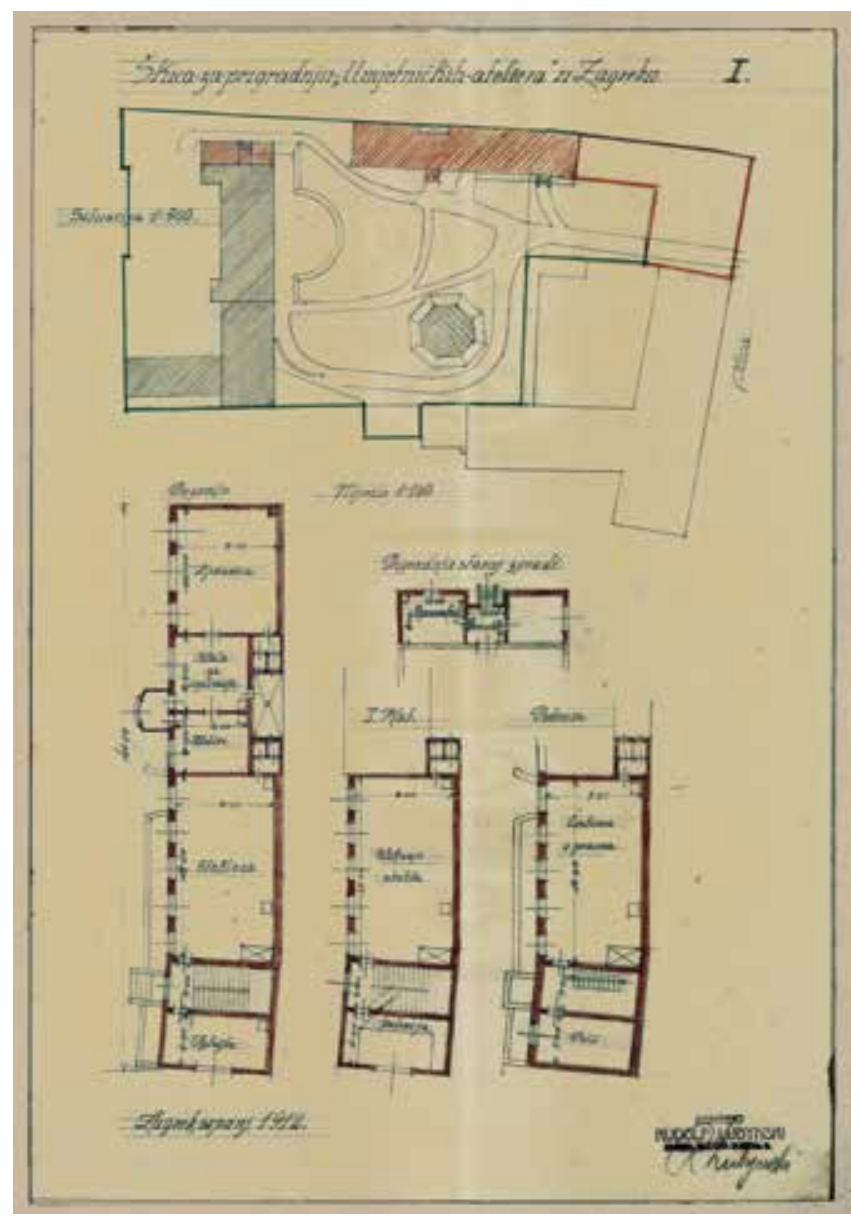

19. Rudolf Lubynski, Škica za prigradnju »Umjetničkih ateliera« $u$ Zagrebu I., Zagreb, srpanj 1912. (Hrvatski državni arhiv, Zbirka građevinskih nacrta)

Rudolf Lubynski, draft for an extension of the "Art Studios" in Zagreb I, Zagreb, July 1912

volumena niskoga izložbenog prostora sprijeda i visoke glavne zgrade, te brojni detalji, veliki trodijelni kvadratni i mali ovalni prozori, polukružni portal i kasetirane vratnice upućuju na rana djela tih arhitekata. ${ }^{60}$

Godine 1912. Robert Frangeš izrađuje Nacrt osnove zakona o ustrojenju Višs škole za umjetnost $i$ umjetni obrt u kojem ponovno naglašava važnost pokretanja arhitektonskog odjela, a odjel umjetničkog obrta znatno se širi zahvaljujući brojnim narudžbama od kojih je najzahtjevnija ona za opremanje Kraljevske sveučilišne knjižnice. Iz te su godine poznata tri projekta koja razrađuju varijante proširenja Više škole. Prvi predviđa preraspodjelu postojećih atelijerskih prostora i gradnju nove zgrade u južnom dijelu, u kojoj bi pod istim krovom bio atelijer profesora Frangeša, škola za kipare i ljevaonica. ${ }^{61}$ Manja prizemna zgrada bez podruma bila bi podignuta paralelno s postojećom zgradom umjetničkih atelijera, u ravnini s južnim aneksom iz 1908. godine, a prema troškovniku gradnja bi bila od armiranog betona, podovi od bukovih daščica, a u ljevaonici, hodniku i zahodu od betona.

Puno ambicioznija su dva projekta nazvana Škica za prigradnju »Umjetničkih ateliera « u Zagrebu (I. i II) koje potpisuje Rudolf Lubynski, također iz 1912 . godine. ${ }^{62}$ Arhitekt u to 


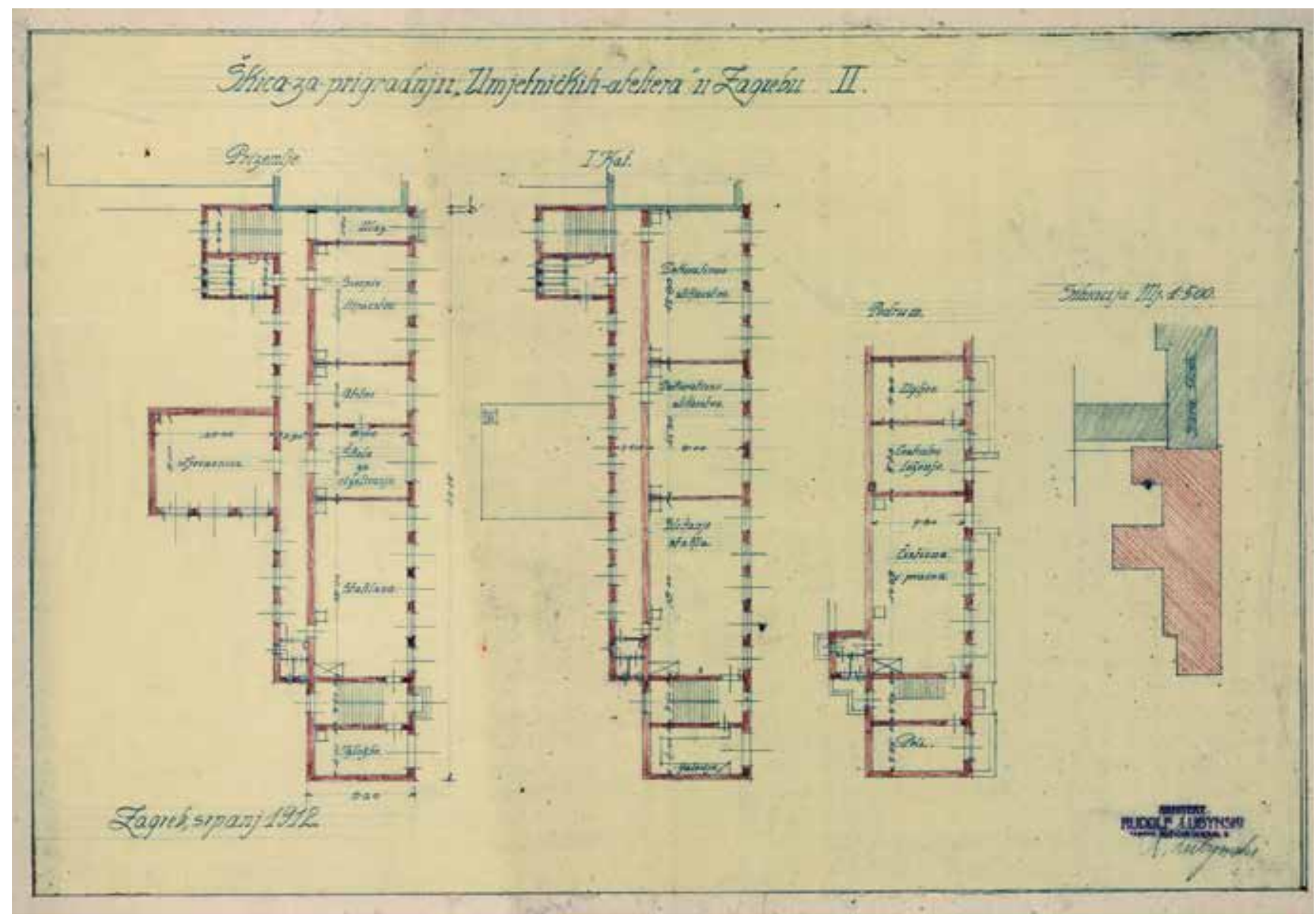

20. Rudolf Lubynski, Škica za prigradnju »Umjetničkih ateliera« u Zagrebu II., Zagreb, srpanj 1912. (Hrvatski državni arhiv, Zbirka građevinskih nacrta)

Rudolf Lubynski, draft for an extension of the "Art Studios" in Zagreb II, Zagreb, July 1912

vrijeme vrlo usko surađuje s profesorima i đacima Više škole koji rade na opremanju novopodignute Sveučilišne knjižnice, te je upoznat s njihovim potrebama. Uz to, planira se još jedna reforma za koju Frangeš sastavlja koncept, Potrebe obrtne i umjetničke škole, u kojem nastoji razlučiti podjelu između odjela obiju škola čije su se aktivnosti preklapale. Prostorne koncepte zgrada, koji se ovdje prvi put objavljuju, Lubynski razrađuje na temelju položajnog nacrta. U prvoj varijanti planira dogradnju staroj zgradi zdesna u kojoj bi bio ured ravnatelja, a velika nova zgrada planira se duž zapadne međe. Izdužen pravokutni objekt bočnim je stranicama orijentiran sjever-jug, a predviđa podrumske prostorije, prizemlje u kojem bi bila ljevaonica, škola za cizeliranje, atelijerski prostor, staklana te izložbeni prostor, dok bi na prvom kata bila radionica slikanja na staklu i galerijski balkon kao nastavak izložbenog prostora u prizemlju koji se proteže kroz dvije etaže. Na drugom je planu ucrtana prigradnja s istočne strane postojeće »stare škole« koja gotovo anticipira kasniju Ivekovićevu zgradu. Predviđen je podrum ispod cijele gradnje, te prizemlje i prvi kat, a s južne strane planirani su manji i veći istaci u kojima su stubište i ljevaonica. Prema toj zamisli u prizemlju je predviđeno sveopće kiparstvo, atelijer, škola za cizeliranje i nasuprotna joj ljevaonica, staklana i izložbeni prostor, a na prvom katu dvije učionice/radionice za deko- rativno slikarstvo, slikanje na staklu i galerija koja je kao i u prvom nacrtu nastavak izložbenog prostora u prizemlju kao jedinstvene cjeline. Lubynski je također predvidio novi glavni ulaz u zgradu na mjestu na kojem je poslije i izveden prema Ivekovićevu projektu.

Od nerealiziranih projekata valja istaknuti i Nacrt za prigradnju umjetničke škole u Zagrebu arhitekta Srećka Florschütza iz 1914. godine. ${ }^{63}$ Kako se u dosadašnjem poznavanju Florschützova opusa taj projekt ne spominje ${ }^{64}$ pridajemo mu značaj kao još jednom pokušaju iznalaženja rješenja za proširenje radnog prostora umjetničke akademije o kojem Uprava trajno razmišlja, a povjereno je još jednom Bolléovu đaku. ${ }^{65}$

Potreba za proširenjem prostora ponovno je aktualizirala u današnje vrijeme pitanje izvedbe vrlo ambicioznog projekta koji bi uključio adaptaciju i nadogradnju postojećih zgrada te izgradnju novih sadržajnih jedinica, rekonstrukciju zgrade u Ilici 83, izgradnju nove zgrade u Ilici 85 s podzemnom garažom i umjetničkom galerijom ALUArtForum. ${ }^{66} \mathrm{Mo}-$ guća nova faza u povijesnom slijedu dogradnji Akademije 


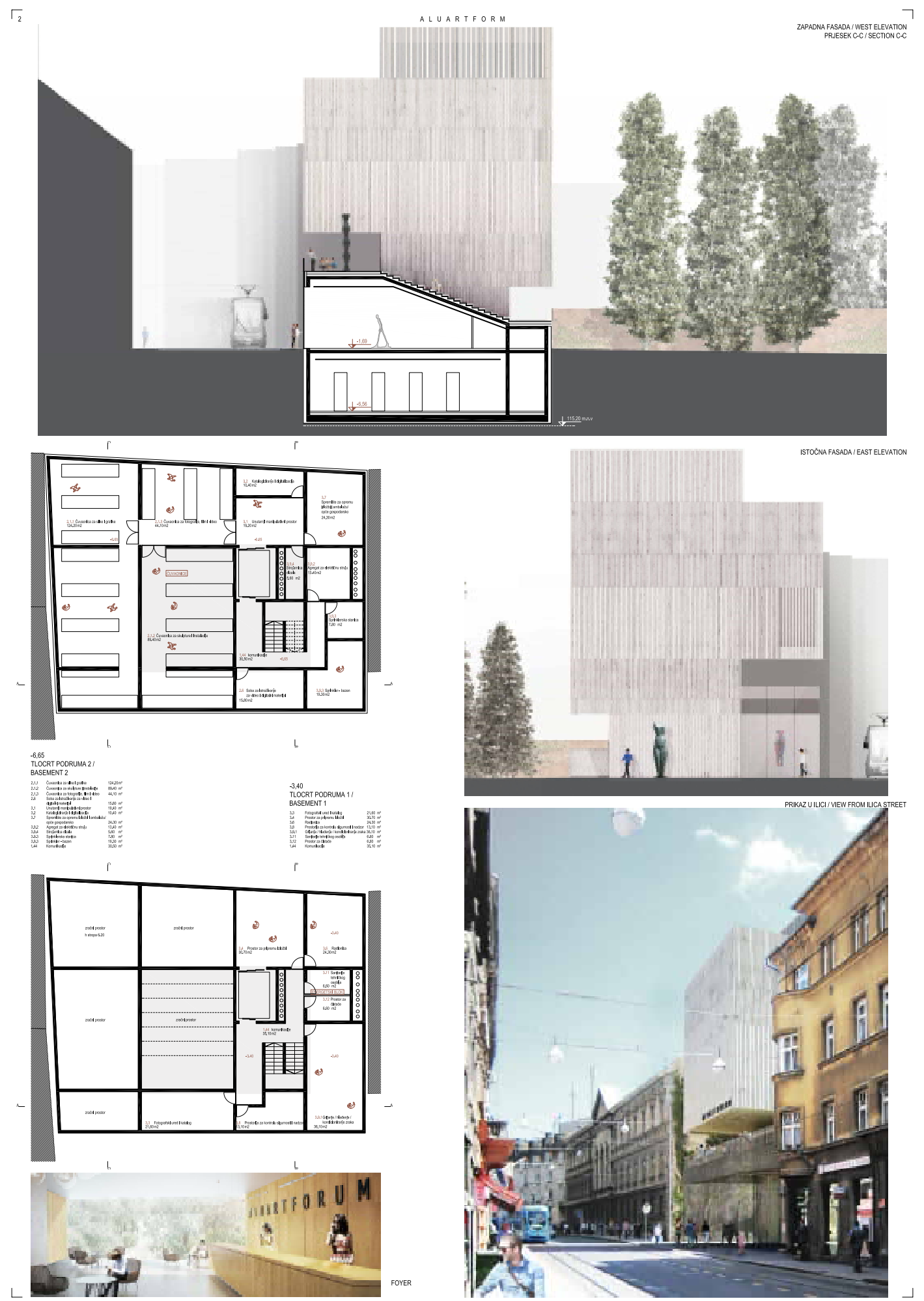

21. Prikaz projekta ALU-Art-Foruma (Arhiv Akademije likovnih umjetnosti)

Presentation of the design of ALUArtForum

likovnih umjetnosti započela je 2007. godine i konkretnije obrise poprimila za dekanskog mandata Dalibora Jelavića. ${ }^{67}$ Sveučilišni kampus ALU u Zagrebu projektiran je s ciljem proširenja i dogradnji novih prostora na postojećoj lokaciji, a studija predizvodljivosti dovršena je prije osam godina. ${ }^{68}$ Veliki moderan blok zgrade galerije zamišljen je s proče- ljem prema Ilici, a osim umjetničke galerije, sadržavao bi i dokumentacijski centar s moderno uređenim prostorima za fundus i arhiv, centar za cjeloživotno obrazovanje, forum za studente, nastavnike, umjetnike i građane. Tim bi se projektom, koji bi trebao poštivati integritet zaštićenoga parkovnog prostora, na Akademiji osigurali preduvjeti za 
visoku kvalitetu umjetničkoga, znanstvenog i pedagoškog rada u budućnosti, i to na mjestu kontinuiranoga umjetničkog djelovanja od 1895. godine, a nakon više od stotinu godina od Kovačićeva i Ehrlichova projekta realizirala bi se interpolacija na praznoj parceli u Ilici. Ostvarenje tog projekta zasigurno će ovisiti o novonastalim okolnostima u Zagrebu nakon potresa 22. ožujka 2020. godine, te o vizijama, planovima i mogućnostima cjelovite obnove grada i same Akademije.

\section{Bilješke}

* Ovaj rad nastao je u sklopu istraživačkog projekta Povijest umjetničkih institucija u Hrvatskoj, PU-IPU -2019-6 (voditeljica: dr. sc. Irena Kraševac)

1

NICOLAUS PEVSNER, Academies of Art. Past and Present, New York, Da Capo Press, 1973. [pretisak prvog izdanja u nakladi Cambridge University Press, 1940.], Poglavlje II, From Leonardo da Vinci to the Accademia di S. Luca, The Sixteenth Century, 25-66.

2

Za povijest umjetničkog školstva u Hrvatskoj naročito su bile poticajne i značajne ustanove (i zgrade) u kojima su se školovali hrvatski umjetnici, kao npr. Kunstgewerbeschule (Heinrich Ferstel, 1877.) i Akademija likovnih umjetnosti u Beču (Theophil Hansen, 1876.) te Akademija likovnih umjetnosti u Münchenu (Gottffried Neureuther, 1886.), izgrađene u historicističkome neorenesansnom stilu.

3

Registar nepokretnih kulturnih dobara grada Zagreba. Zaštićeno kulturno dobro, Z-4740, Narodne novine br. 92/11.

4

O društveno-povijesnim okolnostima gradnje Umjetničkih atelijera i povijesti institucije do razdoblja Prvoga svjetskog rata, vidjeti: OLGA MARUŠEVSKI, Viša škola za umjetnost i umjetni obrt - medij vremena, Peristil, $42 / 43$ (1999./2000.), 115-125; OLGA MARUŠEVSKI, Viša škola za umjetnost i umjetni obrt - medij vremena, u: Akademija likovnih umjetnosti u Zagrebu 1907-1997., monografija u povodu 90. obljetnice Akademije likovnih umjetnosti (ur. Dubravka Babić), Zagreb, 2002., 25-51; OLGA MARUŠEVSKI, Umjetnička kolonija. Od atelijera do Više škole za umjetnost i obrt i Akademije likovnih umjetnosti, u: 1907. Od zanosa do identiteta. Prvi profesori i prvi učenici Akademije likovnih umjetnosti u Zagrebu (katalog izložbe u povodu 100. obljetnice ALU), Zagreb, Umjetnički paviljon, 2007., 18-27; OLGA MARUŠEVSKI, Iso Kršnjavi kao graditelj - Izgradnja i obnova obrazovnih, kulturnih i umjetničkih spomenika u Hrvatskoj, I. izdanje, Zagreb, Društvo povjesničara umjetnosti Hrvatske, Zagreb, 1986., II. izdanje, Institut za povijest umjetnosti, 2009.; OLGA MARUŠEVSKI, Društvo umjetnosti 1868. - 1879. - 1941., Zagreb, Društvo povjesničara umjetnosti Hrvatske, 2004.

5

Inicijativa za gradnju došla je na poticaj Ise Kršnjavija koji u to vrijeme obnaša dužnost predstojnika Odjela za bogoštovlje i nastavu, dok je tadašnji predsjednik Društva umjetnosti Teodor Pejačević. Detaljni historijat Društva umjetnosti povezano s promjenama naziva i obnašateljem dužnosti predsjednika vidjeti u monografiji: 150 godina Hrvatskog društva likovnih umjetnika. Umjetnost $i$ institucija (ur. Irena Kraševac), Zagreb, Hrvatsko društvo likovnih umjetnika - Institut za povijest umjetnosti, 2018.

\section{6}

Primaljsko učilište i rodilište sagrađeno je kao južni aneks Zavoda za gluhonijemu i slijepu djecu, a danas se tim dijelom zgrade koristi Akademija likovnih umjetnosti.

\section{7}

Na samom početku djelovanja adresa Umjetničkih atelijera bila je Prilaz 38, iako se u dokumentima Zemaljske vlade često navodi i adresa Ilica 87. Građevinska dozvola izdana je na adresu Ilica 87. Današnja je adresa Ilica 85.

\section{8}

Danas Centar za odgoj i obrazovanje Slava Raškaj, Ilica 83. Zgrada je podignuta na mjestu prijašnje građevine koju su koristile sestre milosrdnice za bolnicu, rodilište i primaljsko učilište. Nakon niza dogradnji i adaptacija od 1888. do 1894. godine, zadobila je izgled koji ima do danas, s karakterističnim klasicističkim rizalitom i tri visoka lučno zaobljena prozora, prema projektu graditelja Ivana Holza. Ostali graditelji koji su sudjelovali u projektu jesu Johann Gollreider, Fidelis Höppiger i Kuno Waidmann.

\section{9}

Dokumenti povezani s gradnjom Umjetničkih atelijera nalaze se u Hrvatskome državnom arhivu, fond 80, Zemaljska vlada Hrvatske Slavonije i Dalmacije, Odjel za bogoštovlje i nastavu (dalje: HRHDA-80), kut. 133-IV, 1-18; 1/134-IV, 18-29.

10

Odredba glede gradnje umjetničkih ateliera naslovljena na "građevnog savjetnika Hermana Bolléa«, izričito spominje problem nedostatka atelijera za umjetnike kojima su "povjereni radovi na dekoriranju dvorane Kr. zem. vladinog odjela za bogoštovlje i nastavu, zgrade nove gimnazije, realke i trgovačke škole, za obnovu crkve sv. Katarine, crkve u Križevcima«. Pozvani su slikari Bukovac, Medović, Tišov i Čikoš te kipari Frangeš, Valdec i Löwy (Odredba glede gradnje umjetničkih ateliera u Zagrebu, HRHDA-80, kut. 133-IV, br. 1.616, 31. siječnja 1895.). Iso Kršnjavi zapisao je "radi historijske istine « da je inicijativa za gradnju atelijera proizašla iz njegovog razgovora s banom Khuen-Héderváryjem, »baš pred Obrtnom školom «, te je on izravno od Bolléa "naručio nacrt za četiri velika i dva mala atelijera«. Spominje i da je Bollé izradio osnove prema Bukovčevim željama, vidjeti: ISO KRŠNJAVI, Vlaho Bukovac, Umjetnost, 5 (1922.), 3-6; ISO KRŠNJAVI, Pogled na razvoj hrvatske umjetnosti u moje doba. Iz mojih zapisaka, Zagreb, Hrvatsko kolo, 1905.

\section{1}

Građevinska dozvola br. 13641/1895., prosinac 1895., HRHDA-80, kut. 133-IV.

12

Zemaljska vlada obavještava 15. prosinca 1895. slavni Upravni odbor Društva umjetnosti »da je na gruntovnom ulošku br. 283. obćina Zagreb, Donji Grad sagrađena ove godine nova zgrada uređena kao umjetnički atelieri sa cijelim namještajem popisanim u privitku inventara « (HR-HDA-80, kut. 133-IV, 1-18; 1/134-IV, 18-29, br. 19493).

13 Odredba radi opredjeljenja umjetničkih ateliera među slikare i kipare, HR-HDA-80, kut. 133-IV, br. 14 243, br. 17 571, 19. studenoga 1895. Atelijeri u prizemlju dodijeljeni su Medoviću, Ivekoviću i Frangešu, a na katu Bukovcu, Čikošu i Tišovu. 
14

Nazivi prostorija preneseni su prema nazivima na izvornim nacrtima.

15

Jedini sačuvani izvorni prostor atelijera iz Bolléova doba danas je slikarski atelijer na prvom katu u kojem je smješten kabinet Slikarskog odsjeka. Taj je atelijer zadnji koristio umirovljeni prof. Zlatko Kauzlarić Atač.

16

Citat u: DRAGAN DAMJANOVIĆ, Obnova kompleksa zagrebačkog nadbiskupskog dvora 1879. - 1882. godine, Radovi Instituta za povijest umjetnosti, 35 (2011.), 195-206, 204; DRAGAN DAMJANOVIĆ, Gradnja staklenika u vrtu Nadbiskupskog dvora, u: Dragan Damjanović, Arhitekt Herman Bollé, Zagreb, Muzej za umjetnost i obrt - Leykam international, 2013., 358-360.

17

Danas stube koje vode u Arhiv i Fundus ALU.

18

HR-HDA-80, kut. 133-IV, br. 5650, 24. travanj 1895. Nije točno utvrđeno je li ta tvrtka vodila nadzor ili izvodila radove, ali suradnja nije iznenađujuća jer je arhitekt Martin Pilar do svog osamostaljenja, tj. osnivanja tvrtke s arhitektima Julijem Mallyjem i Karlom Baudom 1894. godine, radio u Bolléovu i Waidmannovu arhitektonskom birou. Vidjeti: ZLATKO JURIĆ, Arhitekt Martin Pilar - zagrebački radovi 1889. - 1900., Radovi Instituta za povijest umjetnosti, 18 (1994.), 153-167. Sudjelovanje na gradnji Više škole ne spominje se u popisu Pilarovih izvedenih radova.

19

Pohvalbeni zapisnik, HR-HDA-80, kut. 133-IV, br. 14 243, 12. kolovoza 1896.

20

Bečka tvrtka R. Ph. Wagner (Waagner) bila je poznati proizvođač i dobavljač metalnih konstrukcija. U Hrvatskoj su poznati primjeri spiralna stubišta u tornjevima i riznici zagrebačke katedrale, metalna oprema za crkvu u Mariji Bistrici i konstrukcija pjevališta na željeznim nosačima za crkvu sv. Lovre u Požegi. Zastupstvo tvrtke u Zagrebu vodio je Ferdo Kondrat, arhitekt i građevinski poduzetnik.

21

Zagrebački stolar Josip Šeremet bio je Bolléov suradnik u opremanju unutrašnjosti većine njegovih objekata, a za Umjetničke atelijere napravio je ormare.

22

Svotnik sveukupnih troškova građevnih radnja, unutarnjeg uređenja i inih radnja i dobava novogradnje umjetničkog ateliera u Zagrebu, HR-HDA-80, kut. 133-IV, br. 1712, svibanj 1896.

23

Naredba o uređenju dvorišta i vrta kod novogradnje umj. ateliera u Zgb., HR-HDA-80, kut. 133-IV, 1-18; 1/134-IV, 18-29, broj $4901 / 1896$.

24

Vítězslav Durchánek (1857. - 1924.) u Zagreb je došao iz Češke 1890. godine kao kraljevski vrtlarski nadzornik. Radio je na uređenju Botaničkog vrta, a planirao je i održavao i druge parkovne površine u gradu. O uređenju vrta oko zgrade Umjetničkih ateliera, vidjeti: HR-HDA-80, kut. 134-IV, pril. 12.

ISO KRŠNJAVI (bilj. 10, 1922.). Taj navod citira i OLGA MARUŠEVSKI (bilj. 4, 1999./2000.), 119. Rascvjetale krošnje voćaka zabilježene su na fotografijama iz razdoblja između dvaju ratova. Danas u perivoju raste isključivo ukrasno drveće i grmovi.

26

Atelijeri su nakon izgradnje često mijenjali korisnike, a privremeno je u jednom atelijeru bila i knjižnica Društva umjetnosti.

27

Više molbi s potrebom proširenja prostora upućeno je Zemaljskoj vladi u periodu od 1895. do1907. godine, HR-HDA-80, kut. 133IV $1-18$; 1/134-IV, 18-29.

28

Biografski podatci o Victoru Grossu vrlo su oskudni. Rođen je u Vinkovcima, gdje je i umro, vjerojatno prije 1932. godine, a Graditeljsku školu apsolvirao je 1897. godine. Ime Victor Gross, kako je potpisan na nacrtima (pa tako i u ovom tekstu), može se poistovjetiti s Viktorom Groszom u popisu apsolvenata i polaznika zagrebačke Srednje tehničke škole (Graditeljske škole u sklopu Obrtne škole), što potvrđuje da je bio đak Hermana Bolléa, vidjeti: Državna srednja tehnička škola u Zagrebu 1892/3. - 1932/3. Spomen-izvještaj o 40-godišnjici škole (ur. B. Širola), Zagreb, Državna srednja tehnička škola i Udruženje graditelja kraljevine Jugoslavije, Sekcija Zagreb, 1932., 70; ZLATKO JURIĆ, Školovanje građevinskih obrtnika u Hrvatskoj i Slavoniji od 1850. do 1918., Prostor, 9, 2 [22] (2001.), 119-137. Godine 1907. Gross je gradio standardizirane činovničke najamne stanove na Paromlinskoj cesti 15-17 u Zagrebu.

29

Godine 1907. vlada je raspisala »jeftimbu za dogradnju ateliera«. Nacrti za dogradnju nose datum: veljača 1907. Potpisao ih je građevinski poduzetnik Victor Gross. Građevinska dozvola izdana je 22. svibnja 1907. (HR-DAZG-1122, Zbirka građevne dokumentacije, Ilica 83, sign. 1547/4).

30

Potres od 22. ožujka 2020. ostavio je traga u unutrašnjosti tako da je postao vidljiv spoj između dviju građevina, na kojem je nastalo vertikalno puknuće.

31

Nacrt za dogradnju atelijera »u ključ« izrađen je sporazumno s ravnateljstvom škole u Građevnom odsjeku i ne može se pripisati određenom arhitektu. Zgrada je planirana krajnje jednostavno, ponavljajući tek tipologiju prozora u prizemlju glavne zgrade. Dozvola za gradnju izdana je 15. travnja 1908., tako da je istočna dogradnja realizirana 1907./1908. godine, vidjeti: OLGA MARUŠEVSKI (bilj. 4, 1999./2000.), 121. Prizemna zgrada južnog aneksa dobiva kat između 1914. i 1916. godine, kada se obavljaju i nužne pregradnje, a dio novca pribavljen je prenamjenom sredstava koje je Vlada osigurala za stručno putovanje studenata i profesora Roberta Auera u Italiju, a koje je otkazano zbog rata, kako je obrazloženo dopisom Kr. Zem. Vlade od 20. srpnja 1914., Arhiv ALU, fond Opći spisi ALU, 1914., br. 1818. Prvi kat je, doduše, dosta nespretno povezan s postojećom glavnom zgradom što je vidljivo u spoju i različitim visinama prozora, a ponavlja se identičan raster i tip prozora kao u prizemlju.

32

Isplata, HR-HDA-80, dok. br. 27379, od 2. XI. 1910.

33

Josip (Josef) Dubsky (1868. - 1933.), češki graditelj, u Zagrebu djeluje od 1897. godine. Tvrtka Josip Dubsky i sin bila je koncesionar za gradnje od armiranog betona za Hrvatsku, specijalizirana za mostogradnju. Izvodi i prve armiranobetonske konstrukcije u Zagrebu, silos Paromlina i kupolu crkve sv. Blaža, vidjeti: DRAGAN DAMJANOVIĆ, Secesijski armiranobetonski mostovi vukovarskog inženjera Frana Funtaka, Prostor, 11 (2003.) 1 (25), 
11-31, 16; KREŠIMIR GALOVIĆ, Viktor Kovačić, otac hrvatske moderne arhitekture, Zagreb, EPH Media, 2015., 65-66.

34

Kraljevsko zemaljsko više obrazovalište za umjetnost $i$ umjetni obrt u Zagrebu osnovano je naredbom zemaljske vlade od 22. travnja 1907. br. 12594. Od listopada 1907. naziv je Privremena viša škola za umjetnost $i$ obrt, tek zakonskom odredbom od 19. travnja 1918. naziv je Kraljevska viša škola za umjetnost i umjetni obrt. Zagrepčani su je kolokvijalno zvali Umjetnička škola.

35

TAJANA VRHOVEC ŠKALAMERA, Profesori i učenici, u: 1907. Od zanosa do identiteta. Prvi profesori i prvi učenici Akademije likovnih umjetnosti u Zagrebu (katalog izložbe u povodu 100. obljetnice ALU), Zagreb, Umjetnički paviljon, 2007., 53-55.

36

Ćiril Metod Iveković (Klanjec, 1864. - Zagreb, 1933.) nakon školovanja na Višoj obrtnoj školi u Beču, godine 1884./1885. radi u zagrebačkom atelijeru Hermana Bolléa, pomaže na restauraciji zagrebačke katedrale i nadzornik je restauracije grkokatoličke crkve u Ćirilometodskoj ulici. Bollé mu povjerava projekte $\mathrm{s}$ proračunom troškova za crkve u Ravnoj Gori i Erdeviku. Postavljen je za predstojnika Odjela za klesare i zidare na Obrtnoj školi, a njegovi su učenici bili Frangeš i Valdec. Zbog nesuglasica s Bolléom Iveković dobiva otkaz, pa nastavlja studij na Akademiji likovnih umjetnosti u Beču, Spezialschule für Architektur, kod profesora Karla von Hasenauera. Po završetku studija 1889. radi $\mathrm{u}$ Hasenauerovu atelijeru, a godinu potom kao samostalni arhitekt kod bosanskohercegovačke zemaljske vlade u Sarajevu. Od 1896. preuzima mjesto referenta za bogoštovne zgrade u Dalmaciji, sa sjedištem u Zadru. Nakon imenovanja profesorom arhitekture na Visokoj tehničkoj školi u Zagrebu, osnovanoj 1919., vraća se u Zagreb 1920. godine. Uz angažirani nastavni rad, projektira obiteljske kuće (kuća Milana Šenoe u Mallinovoj ulici 27, 1925.; vlastita kuća u Bosanskoj 31, 1927.), glavni portal i postaje Križnog puta na Ksaveru te stambeno-poslovnu zgradu u ulici Franje Račkoga 11, podrobnije u monografiji: SLAVICA MARKOVIĆ, Ćiril Metod Iveković. Arhitekt i konzervator, Zagreb, Društvo povjesničara umjetnosti Hrvatske, 1992., u kojoj su popisana i valorizirana njegova djela te sveobuhvatno predstavljeno njegovo arhitektonsko, arheološko i konzervatorsko-restauratorsko djelovanje, no izostavljen je podatak o dogradnji Akademije likovnih umjetnosti u Zagrebu.

37

Arhiv Akademije likovnih umjetnosti u Zagrebu (dalje: Arhiv ALU), fond Građevinska dokumentacija ALU.

\section{8}

Stjepan Wutte (Zagreb, 1888. - Zagreb, 1966.), završio je Graditeljsku školu i u početku radio na Bolléovim projektima. Obitelj je francuskog podrijetla. Stjepanov otac Ivan Wutte bio je zidarski majstor, a stanovao je u Mesničkoj ulici. Stjepan je radio u suradnji ili samostalno kao ovlašteni graditelj. Godine 1927. kupuje veće zemljište i gradi obiteljsku vilu u Podsusedu (danas Vrtni centar). Iza kuće prema željezničkoj prugi imao je tvornicu betonskih proizvoda Ferobeton iz koje je poslije 1945. nastala Samoborka. Između dvaju svjetskih ratova, u jeku najveće aktivnosti, gradio je obiteljsku vilu u Mlinarskoj 53 (zaštićeno kulturno dobro Z-0654, Narodne novine br. 58/07) te stambeno-najamne zgrade na lokacijama Tratinska 28 i Ribnjak 2. Surađivao s je Rudolfom Lubynskim na gradnji zgrade zdravstvenog osiguranja u Mihanovićevoj ulici. Posljednji rad mu je tvornica za preradu voća u Donjoj Stubici (DONA), građena tijekom Drugoga svjetskog rata, a nakon rata više nije bio aktivan. Podatci su dobiveni od kćeri Renate Cabor. Wutte i Mihok izradili su i (neizvedeni) projekt trgovačke kuće dvorištu u Ilici 13/1, 1922.
(Kuće Stöger i Kolmar, lica 12-13/1, zaštićeno kulturno dobro, Z-2656, NN 124/06). Mihok će se poslije povezati s Ottom Goldscheiderom s kojim radi od 1924. do 1934. godine.

39

FEDOR KRITOVAC, Natpisi i oznake graditelja na zagrebačkim zgradama, Prostor, 9 (2001.), 87-88.

40

Građevinski dnevnik prigradnje Kraljevske akademije za umjetnost i umjetni obrt, arhitekt Ć. M. Iveković, građevno poduzetništvo Wutte i Mihok, Ilica 47, Arhiv ALU, fond Građevinska dokumentacija ALU.

41

Do 1921. godine svi su podovi bili drveni.

42

Do četvrte dogradnje, 1950-ih godina, ulazna vrata bila su postavljena u visini razizemlja, a tada su radi izjednačavanja visine s nadograđenim južnim dijelom postavljena na razinu prizemlja i natkrivena trijemom sa stubama. Projekt novog ulaza i predvorja napravio je arhitekt Ivo Geršić. U toj rekonstrukciji nestaje profilirani vijenac i natpis ustanove.

43

Na nacrtu je potpis Jar Albert. Građevno poduzeće Pollak - Albert - Bornstein (kasnije Pollak - Bornstein) djelovalo je od 1911. do 1941. godine u Gajevoj ulici u Zagrebu; Arhiv ALU, fond Građevinska dokumentacija.

44

Arhiv ALU, fond Opći spisi ALU 1956., broj 501, 24. travnja 1956. 45

Do 1962. godine čelnik Akademije nosi naziv rektor. Frano Kršinić je funkciju rektora obnašao od 1952. do 1954., a Vanja Radauš od 1954. do 1956. godine.

46

Zapisnici Sjednica Odbora za prigradnju akademije 1954. - 1956., Arhiv ALU, fond Građevinska dokumentacija ALU.

47

IVO GERŠIĆ, Izgradnja školskih zgrada, u: Spomenica Akademije likovnih umjetnosti u Zagrebu. Prigodom 50-godišnjice njenog osnutka (1907/8. - 1957/8.), Zagreb, Akademija likovnih umjetnosti - Izdavački Zavod Jugoslavenske akademije znanosti i umjetnosti, 1958.

48

Ivo Geršić (Slavonski Brod, 1915. - Zagreb, 2002.), diplomiravši na Tehničkom fakultetu u Zagrebu 1938. godine, radio je u Tehničkom odsjeku gradskog poglavarstva u Zagrebu i u Sekciji za održavanje pruga u Slavonskom Brodu. Veći dio radnog staža ostvario je u Arhitektonskom projektnom zavodu u Zagrebu. Predavao je kao vanjski suradnik predmete Perspektiva i Nauka o stilovima na Akademiji likovnih umjetnosti u Zagrebu od 1950. do 1963. godine. Projektirao je i izveo dvadesetak zdravstvenih i školskih zgrada, između ostalog osnovnu školu na Mlinarskoj cesti, Školu učenika u privredi tekstilne struke »Đuro Salaj« (danas Škola za modu i dizajn) na Prilazu baruna Filipovića, te izveo višekatne stambene zgrade na križanju Držićeve i Ulice grada Vukovara. Bio je član Savjeta Međunarodne federacije za gradnju bolničkih zgrada (International Federation of Healthcare Engineering).

49

Cjelovit projektni elaborat za izradu namještaja čuva se u Arhivu ALU, fond Građevinska dokumentacija ALU, Akademija likovnih umjetnosti, Namještaj upravnog trakta dogradnje školske zgrade, Detaljni nacrti, Zagreb, 22. X. 1956., Ing. Bihler. 
50

Arhitektica Fanika Bihler (Büchler, 1919. - 1996.) nedovoljno je valorizirano ime hrvatske arhitekture i dizajna 1950-ih i 1960-ih godina, kada intenzivno sudjeluje u projektiranju unutrašnjeg uređenja (opreme) obrazovnih, odgojnih i zdravstvenih ustanova. Osim s arhitektom Geršićem, surađivala je is arhitektom Bernardom Bernardijem, primjerice na oblikovanju cjelovite opreme zagrebačkog Oglednog dječjeg vrtića pri Školi za odgajatelje u Habdelićevoj ulici (1951.), vidjeti: IVA CERAJ, Ergonomski pristup: lakoća i složivost opreme za obrazovne procese, u: Iva Ceraj, Bernardo Bernardi: dizajnersko djelo arhitekta 1951. - 1985., Zagreb, Hrvatska akademija znanosti i umjetnosti, 2015., 190.

51

Tijekom posljednje obnove i adaptacije Akademije, 2006. godine, došlo je do nepovratnog gubitka dijela opreme interijera i devastacije uzornog primjera total-dizajna.

\section{2}

Izvedba namještaja povjerena je drvnom proizvodnom poduzeću (DPP) Marko Šavrić iz Zagreba. Poduzeće je osnovano nakon Drugoga svjetskog rata, nacionalizacijom više stolarskih radionica, a kvalitetnom izvedbom svojih proizvoda osiguravalo je, uz pojedinačnu prodaju, poslove na opremi javnih ustanova. Fanika Bihler je često na svojim projektima surađivala s tom tvrtkom.

\section{3}

Od 2006. do 2010. godine obnovljena je zgrada Akademije likovnih umjetnosti. Sva su pročelja, osim Geršićeva trakta, dobila jednolike žute fasade, a veliki dvostruki rešetkasti prozori nekadašnjih Umjetničkih atelijera zamijenjeni su novima, s debljim metalnim okvirima.

54

Ministarstvo kulture, Uprava za zaštitu kulturne baštine, Ostavština Viktora Kovačića (MK-UZBK-OVK, Kovačić-Ehrlich), inv. 981, 982, 983, 984, 985, 986, 987, 988, 989, 990, 993.

\section{5}

OLGA MARUŠEVSKI (bilj. 4, 1999./2000.). Uz tekst je reproducirano osam nacrta. Isti tekst i reprodukcije objavljeni su u monografiji Akademije likovnih umjetnosti (bilj. 4, 2002.)

\section{6}

Visoka kralj. Zemaljska vlado. Rukopis tajnika Zdenka Šenoe s potpisom Mencija Klementa Crnčića, br. 50/1909, 8. veljače 1909. (Arhiv ALU).

\section{7}

OLGA MARUŠEVSKI (bilj. 4, 1999./2000.), 121-122, navodi da je gradnja zaustavljena na Građevnom odsjeku i citira Tomislava Krizmana koji rezignirano konstatira da je »samo jedan dan Mixicheve vladavine manjkao da bi zemaljska vlada potvrdila gradnju velike dvokatne zgrade za umjetničku školu«. TOMISLAV KRIZMAN, Naša umjetnička škola, Obzor, 49, 4.3.1910., 3. Ferdinand (Ferdo) Mixich bio je predstojnik Odjela za bogoslužje i nastavu od 1908. do 1910. godine. Predstojnik vladina Građevnog odsjeka bio je Juraj Augustin, a njegov savjetnik Augustin Pisačić; isti je dvojac Kovačiću osporavao korištenje naslova arhitekt radi nepriznavanja diplome bečke Akademije likovnih umjetnosti. Taj spor je započeo 1908. godine, vidjeti: KREŠIMIR GALOVIĆ (bilj. 33). 70-71.

\section{8}

Suradnja Viktora Kovačića s umjetnicima/profesorima Više škole bila je vrlo bliska još od osnutka Društva hrvatskih umjetnika 1897. i izložbe Hrvatski salon 1898. godine, te suradnje na časopisu Život. Kovačić je autor projekata i realizacija slikarskog atelijera i vile Auer u Rokovoj ulici 9 (1904. - 1906.) i vile Frangeš, Rokov perivoj 2 (1909. - 1911.).
59

Premda je zajednički arhitektonski atelijer Kovačić i Ehrlich osnovan početkom 1910., njihovo poznanstvo i zajedničko promišljanje arhitekture seže u doba studija u Beču, a nastavit će se tijekom prvog desetljeća 20. stoljeća, i prije Ehrlichova dolaska u Zagreb 1909. godine. Natječaj za gradnju nove zgrade umjetničke akademije u Ilici nije bio raspisan, pa je projekt zacijelo plod izravne suradnje Frangeša i ostalih umjetnika/profesora s Kovačićem. Mišljenja smo da su nacrti koji nose njemačke nazive (Kunstschule in Agram) Ehrlichov rad, a nacrti Gradnja škole za umjetnost u Zagrebu, Kovačićev. Ehrlich razvija ideju pročelja, kolnog ulaza i izložbene galerije, a Kovačić crta presjeke i tlocrte.

60

Pročelje se može usporediti s nešto kasnijom stambeno-poslovnom zgradom Hipotekarne banke za promet nekretninama u Ilici 100, za koju su Ehrlich i Kovačić nacrte izradili 1912. godine, vidjeti: ŽARKO DOMLJAN, Arhitekt Hugo Ehrlich, Zagreb, Društvo povjesničara umjetnosti Hrvatske, 1979., 75-79; KREŠIMIR GALOVIĆ (bilj. 33), 71-72. Premda autori ta dva projekta ne dovode u vezu, zgrada je vrlo sličnih proporcija, zapravo ponavlja pročelje nesuđene akademije s pet prozorskih osi bez istočnog dijela s kolnim ulazom. Kada se oduzme taj dio i dva prozora, ostaje gotovo identično pročelje sa srednjim ulazom koji markira mali balkon, a koji pridržava zaglavni kamen s dekorativnim reljefnim maskeronom, kakav je predviđen i na glavnom portalu umjetničke škole. Četiri polukružna luka označavaju trgovačke prostore u prizemlju, a duž tri etaže protežu se tanki pilastri s jednostavnim kapitelima i plitke kvadratične lezene na fasadnim plohama između katova. Završni vijenac ponavlja istovjetan motiv triglifa i metopa kakav je vidljiv na nacrtu Kunstschule in Agram. Kvadratični prozori prvog kata isto tako slijede jednaku trodijelnu podjelu, a ograda balkona sliči rešetkama predviđenim na podrumskim prozorima nacrta Umjetničke škole. Kao moguća interpolacija u uličnom nizu, projekt je, dakle, umjesto u Ilici 85, modificiran i iskorišten na suprotnoj strani iste ulice. U prilog zaključku da je pročelje Umjetničke škole komponirao Ehrlich ide i činjenica da je on imao glavnu riječ u projektiranju zgrade u Ilici 100 .

61

Nacrti: Škica za dogradnju umjetničke škole u Zagrebu; Umjetnički atelieri u Zagrebu i Aproksimativni proračun troškova od 28. ožujka 1912., sastavljeni su u Odjelu za bogoštovlje i nastavu (potpis na dokumentima nije pročitan). HR-HDA-804, Iso Kršnjavi, kut. 1. Kopije se nalaze u Arhivu Maruševski na Institutu za povijest umjetnosti u Zagrebu.

62

Škica za prigradnju »Umjetničkih ateliera« u Zagrebu I. i Škica za prigradnju »Umjetničkih ateliera « u Zagrebu II., Rudolf Lubynski, Zagreb, srpanj 1912. (HR-HDA-905, Zbirka građevinskih nacrta).

63

Nacrt i popratni dopis od 18. srpnja 1914. s aproksimativnim troškovima čuva se $\mathrm{u}$ Arhivu ALU, $\mathrm{u}$ fondu Građevinska dokumentacija ALU.

64

JASENKA KRANJČEVIĆ, Graditelj Srećko Florschütz, 1882. 1960., Prostor, 2, 1-2 (1994.), 135-152; JASENKA KRANJČEVIĆ, Graditelj Srećko (Feliks) Florschütz. Novi prilozi za poznavanje arhitektonskog opusa, Prostor, 5, 2 (1997.), 273-294.

65

Državna srednja tehnička škola u Zagrebu 1892/3. - 1932/3. (bilj. 28), 69. 
66

Autori projekta ALUArtForum su arhitekti Aleš Žnidaršić, Katja Žlajpah i Andrea Donatović Poljičak. Autori Studije predizvodljivosti su Akademija likovnih umjetnosti (Dalibor Jelavić, Peruško Bogdanić, Slavomir Drinković te Boris Čupić), Arhitektonski fakultet, Sveučilište u Zagrebu i Mreža znanja d. o. o.

67

Dalibor Jelavić bio je dekan Akademije od 2010. do 2012. godine.
68

Natječaj za izradu arhitektonsko-urbanističkog rješenja Umjetničke galerije Akademije likovnih umjetnosti ALUARTFORUM, vidi: http://www.d-a-z.hr/hr/natjecaji/rezultati/natjecaj-za-izradu-arhitektonsko---urbanistickog-rjesenja--umjetnicke-galerije-akademije-likovnih-umjetnosti-aluartforum,110.html? $\mathrm{t}=\mathrm{d}$; http://www.unizg.hr/fileadmin/rektorat/O_Sveucilistu/Jucer_danas_sutra/Poslovanje/razvojni_projekti/Aluartforum/PREZENTACIJA_1.pdf.

\section{Summary}

Irena Kraševac - Ariana Novina

\section{Plans and Stages in the Construction of the Academy of Fine Arts in Zagreb (1895-1957)}

Respect for the 125-year tradition of continuous operation of Zagreb's Academy of Fine Arts (ALU), located in a courtyard building at Ilica 85, which is listed in the Register of Immovable Cultural Property of the City of Zagreb, imposes the need for better knowledge of the historical circumstances in which its construction took place. The main building of ALU Zagreb was built in various stages from 1895 to 1957. During the first sixty years, from the late $19^{\text {th }}$ to the mid- $20^{\text {th }}$ century, its central building was planned and built, and the then most renowned Croatian architects and builders participated in its architectural conception and realization. This article analyses in detail for the first time all the individual phases of construction and the unrealized projects.

The original building of today's Academy of Fine Arts consisted of four large and two smaller art studios, built according to a project of Herman Bollé in 1895/1896. Along with the founding of the College of Arts and Crafts in 1907, of which art studios became an integral part, builder Victor Gross made plans for the first major extension to the east, with a wing to it towards the south of the plot, whereby he fully respected Bolle's earlier project. The building was further enlarged shortly after World War I, when the school was reformed, new programs were introduced and it obtained the status of an academy, which required additional facilities. Construction of the eastern annex began in 1921, and the three-storey building with a loft that leaned directly on Gross's extension of Bolle's first art studios was designed by architect Ćiril Metod Iveković. In 1954, a new building was added, a four-storey wing protruding on the south side, which leaned laterally on the existing building by Iveković with the intention of functionally designing the rooms according to the needs of modern teaching in both practical and theoretical subjects. The construction lasted until 1957, and its designer and construction manager was the architect Ivo Geršić. In addition to the main architectural project, a project study for the production of furniture for the administrative tract was commissioned from architect Fanika Bihler. This completed the almost half-century-long construction and extension of the Academy of Fine Arts, which was ultimately work of several builders through several generations, and can be considered as a collective work of Herman Bollé, Victor Gross, Ćiril Metod Iveković, and Ivo Geršić. The representative character of its architecture was subordinated to its purpose of housing art studios, and its position in the depth of the plot emphasized this. Instead of decorative historicism in the style of its time, the purity and simplicity of architecture characteristic of Bollé s first studios were emphasized, which made it possible to add extensions harmoniously over a period of almost sixty years.

The history of ALU's construction would remain incomplete without mentioning various envisioned, elaborated, yet unrealized projects for additions and extensions. The most comprehensive project documentation included designs attributed to Viktor Kovačić and Hugo Ehrlich, who planned a new building on an undeveloped plot in Ilica. Refined architectural concept with hints of "classical" modernism and numerous details point to the early works of these architects. Two projects signed by Rudolf Lubynski, likewise from 1912, included plans for enlarging the existing building and erecting a new one at the western edge of the plot. Lubynski envisioned an addition to the east of the existing "old school", which almost anticipated Iveković's later construction. The need to gain more space brought to the fore the issue of constructing the Campus and the ALUArtForum for the $21^{\text {st }}$ century, which would include the adaptation and enlargement of the existing buildings and the construction of new facilities, reconstruction of the building at Ilica 83, and construction of a new building at Ilica 85 , an underground garage, and the art gallery ALUArtForum. Realization of these plans will certainly depend on the new circumstances in Zagreb after the earthquake of March 22, 2020, as well as the visions, plans, and capacities for a complete reconstruction of both the Academy and the city as a whole.

Keywords: Art ateliers, Academy of Fine Arts in Zagreb, architecture, Herman Bollé, Victor Gross, Viktor Kovačić, Hugo Ehrlich, Rudolf Lubynski, Srećko Florschütz, Ciril Metod Iveković, Jaroslav Albert, Ivo Geršić, Fanika Bihler 